\title{
Optical Components for High Speed Optical Communications
}

\author{
Yongsoon Baek $^{\dagger}$ \\ Optical Internet Components Research Team, Electronics and Telecommunication Research Institute, \\ Daejeon 305-700, Korea
}

(Received November 26, 2013; Accepted December 5, 2013)

\begin{abstract}
With the explosive growth of internet data traffic due to the FTTH penetration, prevalence of smart devices and cloud network service, the demand for higher bandwidth is ever increasing with the pace of more than $40 \%$ annual growth. To accommodate ultra high bandwidth traffic, optical components in each hierarchy have progressed rapidly. WDM has begun to be deployed along with higher bandwidth service in the access network. Next-generation ROADM is under development for efficient network management in the metro network. For long-haul transmission, an advanced modulation scheme based on coherent transmission technology has been adopted to enhance spectral efficiency. In this paper, core components to meet the demands of high speed, high efficiency and low power consumption will be reviewed.
\end{abstract}

Keywords: Optical communications, Optical components, Coherent communications

OCIS codes: (060.2340) Fiber optics components; (060.2380) Fiber optics sources and detectors; (060.1660) Coherent communications

\section{대용량 광통신 부품 기술 동향 \\ 백용순 $^{\dagger}$}

한국전자통신연구원 광인터넷부품연구실

우 305-700 대전시 유성구 가정로 218번지

(2013년 11월 26일 받음, 2013년 12월 5일 게재 확정)

스마트 기기, 클라우드 서비스, 광가입자망 등의 보급에 따른 멀티미디어 기반의 대용량 인터넷 트래픽의 급속한 증가로 통신 수요는 연 $40 \%$ 이상씩 증가하고 있다. 이러한 대역폭 증가를 수용하기 위해서 광통신용 광부품의 진화도 각 계층별로 빠르게 진행되고 있다. 가입자망에서는 변조속도 증가와 더불어 파장다중방식의 도입이 시작되고 있고, 매트로망에서는 보다 효율적인 망 운용을 위해 차세대 ROADM에 대한 개발이 진행중이며, 장거리 통신에서는 코히어런트 통신 기반의 새로운 변조방식이 도입 되어 스팩트럼 효율을 향상시키고 있다. 본 논문에서는 이러한 폭발적인 통신 대역폭 증가 요구에 따른 광통신망의 진화와 이를 수용하기 위한 고속화, 효율화, 저전력화로 발전하고 있는 핵심 광부품에 대해 살펴본다.

Keywords: 광통신, 광통신부품, 코히어런트통신

OCIS codes: (060.2340) Fiber optics components; (060.2380) Fiber optics sources and detectors; (060.1660) Coherent communications

\section{I. 서 론}

1990년대 인터넷의 보급으로 시작된 통신 수요의 급속한 증가는 2000년대 초반 통신시장의 거품이 꺼지면서 광통신 시장의 위축을 불러 왔지만 이후에도 통신 수요는 지속적으 로 증가해왔고 근래에 들어서는 광가입자망의 포설과 스마 트 기기, 클라우드 서비스 등의 보급에 따라 대용량 통신 수 요는 폭발적인 증가세를 보이고 있고 향후에도 지속될 것으
로 예측되고 있다. 1960년대에 개발된 반도체 레이저와 1970 년대에 개발된 저손실 광섬유를 기반으로 1980년대부터 본 격적인 광통신 시대가 개막되었고 1990년대에는 광섬유 광 증폭기의 발전과 파장다중분할(WDM: Wavelength Division Multiplexing) 방식의 도입으로 그림 1 에서 보듯이 광통신 용 량은 현재까지 수십만 배가 넘는 놀라운 증가를 지속하고 있다.

광통신은 시간다중분할(TDM: Time Division Multiplexing) 방식을 이용하며 여러 신호를 시간축에서 조합하며 변조 속

\footnotetext{
${ }^{\dagger}$ E-mail: yongb@etri.re.kr

Color versions of one or more of the figures in this paper are available online.
} 


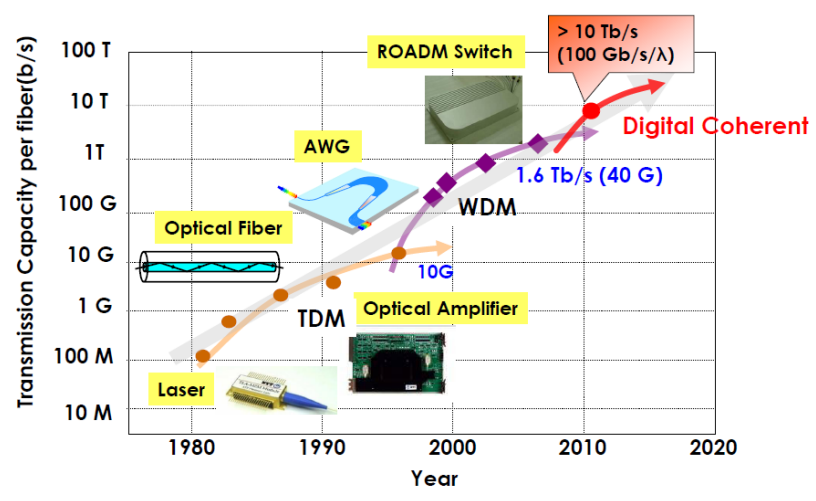

FIG. 1. Progress in optical network.

도 증가를 통해 전송 속도를 늘려 왔으며 90년대 들어 여기 에 서로 다른 파장간에 간섭이 없는 광의 성질을 이용한 파 장다중분할(WDM: Wavelength Division Multiplexing) 방식 을 병행하여 하나의 광섬유를 통해 여러 개의 파장을 함께 전송하는 방법으로 전송 용량을 크게 늘렸다. 하지만 근래에 들어 폭발적으로 늘어나는 통신 수요의 증가는 지금까지는 거의 무한대처럼 보이던 광섬유의 대역폭이 2020년경에는 한계에 도달할 것으로 예측되어 광통신 방식의 근본적인 변 화를 요구하는 단계에 다다르고 있다. ${ }^{[1]}$ 이는 광통신 대역폭 증가를 위한 물리적인 변조 속도의 증가는 전자소자의 속도 증가 포화 현상 및 발열 등의 문제로 한계점에 다다르고 있 고 장거리 전송에 필요한 광섬유 증폭기의 사용이 가능한 파 장 대역도 고정된 파장 규격을 갖는 기존 통신 방식에서는 거의 소진되어 새로운 전송 방식이 필요하기 때문이다. 이로 인해 $40 \mathrm{Gbps}$ 이상의 초고속 장거리 통신에는 기존 심볼당 1 비트를 전송하는 광세기 변조방식(OOK: On-Off Key)에서 위상 및 멀티레벨 변조를 이용하는 진보된 변조 방식을 도입 하여 심볼당 여러 비트의 신호전송을 통해 스팩트럼 사용 효 율을 높이는 방식이 도입되고 있다. ${ }^{[2]}$

한편 광통신은 전송 용량이 크고 손실이 작으며 상대적으 로 고가인 특성 때문에 초기에는 장거리 통신에만 사용되었 다. 그러나 통신 용량의 증가에 따라 그 적용 범위를 넓혀, 보다 짧은 거리의 도시 간을 연결하는 통신에 활용되기 시작 했고 2000 년대 중반부터는 마침내 개별 가입자에게까지 광 통신이 보급되는 시대를 맞이하게 되었다. 이와 같이 장거리 전송에서, 도시 간 통신, 가입자망까지 적용 범위를 확대함 에 따라 광통신망은 자연스럽게 계층 구조를 가지게 되었고 각 계층 별로 다른 요구사항에 따라 발전해 왔으며 그 계층 구도는 그림 2 와 같다.

주로 대륙 간을 연결하는 장거리 전송(Long haul)의 경우 전송거리가 수천 $\mathrm{km}$ 에 이르며, 도시 간을 연결하는 매트로 망의 경우 수백에서 천 $\mathrm{km}$ 정도를 거리를 담당하며, 가입자 망의 경우 현재는 최대 20 30 km 정도의 거리를 포함한다. 각 계층별로 통신 거리뿐 아니라 통신 방식, 그리고 통신 속 도 등 각각 다른 요구 사항을 가지므로 이에 따라 최적화된 광부품이 개발되고 있다. 또한 최근 급격히 늘어나고 있는

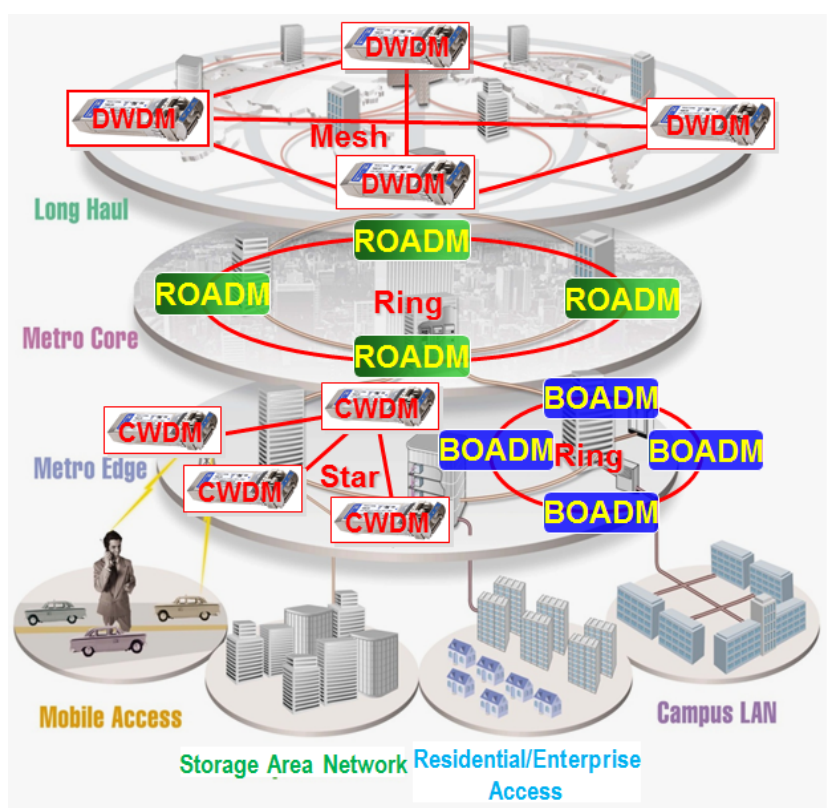

FIG. 2. Schematic diagram of optical network hierarchy.

대용량 데이터를 효율적으로 처리하고 공급하기 위한 대규 모 데이터 센터의 건설로 데이터 센터 내 또는 데이터 센터 사이의 대용량 통신에도 광통신이 사용되기 시작했다. 이러 한 광가입자망의 보급과 데이터 센터의 광통신 수요는 전에 없던 많은 양의 광부품 수요를 발생시켜 기존 고품질, 고가 격의 광부품 시대에서 저가격, 소형, 저전력 소모의 광부품 개발이 핵심 요구 사항으로 등장하고 있다. 한발 더 나아가 데이터 처리 속도의 증가에 따라 초단거리 보드레벨 통신에 까지 구리선 통신 대신 광인터커넥션을 도입하는 연구가 진 행되고 있으며 컴퓨터의 CPU와 메모리 사이의 통신도 광으 로 연결하는 시대가 도래할 것으로 예측되고 있다. 이러한 급속한 환경 변화에 따라 광통신 부품은 통신 속도, 거리 및 적용 대상에 따라 최적화된 구조로 발전하고 있으며 이와 함 께 저가화, 소형화, 저전력화를 구현하는 방향으로 발전하고 있다. 본 논문에서는 광통신 계층 구조에 따라 광가입자망, 매트로망, 장거리 통신용 광부품으로 구분하여 망의 특징과 핵심 광부품에 대해 살펴 본다.

\section{II. 가입자망용 광부품 기술}

1990년대 인터넷의 보급으로 광대역 가입자망 통신 수요 가 시작되었다. 초기에는 구리선을 이용한 서비스가 제공되 었으나 전송거리 및 대역폭의 제한으로 광가입자망의 보급 이 2000년대에 들어 본격적으로 이루어지기 시작했다. 우리 나라의 광대역 가입자 서비스는 보급률 및 제공되는 통신 속 도 면에서 세계 최고 수준을 자랑하고 있으며 한걸음 더 나 아가 방송통신위원회의 "미래를 대비한 인터넷 발전계 획"(2011. 6.)에 의하면 향후에도 유선 가입자망은 UHDTV, 홀로그램, 가상현실 등 비디오 콘텐츠 중심의 트래픽에 의해 


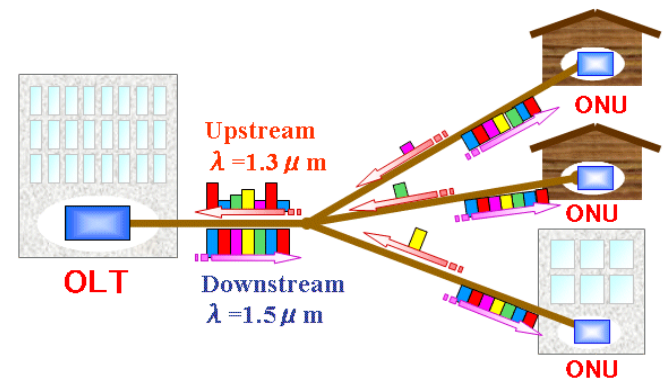

(a)

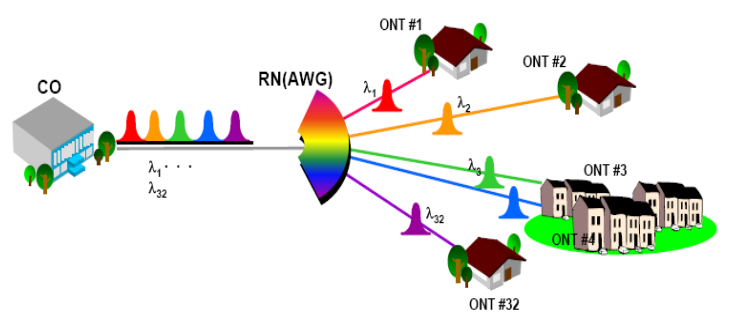

(b)

FIG. 3. Schematic configuration of (a) TDM-PON, (b) WDM-PON.

2020 년에는 최대 $4 \mathrm{Gbps}$ 의 대역폭이 소요될 것으로 예측되 어 지속적인 투자가 진행될 것으로 전망된다.

광가입자망의 가장 큰 특징은 앞서 언급한 바와 같이 기존 통신망 구축과는 비교할 수 없는 대규모 광통신 부품 수요에 있다. 또한 가입자망은 주로 전화국과 가입자간의 연결로 점 대다점(point-to-multi point) 연결 성격을 가지고 있다. 따라 서 광가입자망의 구성방식은 이러한 상황을 반영하여 대부 분 수동가입자망(PON: Passive Optical Network)으로 구성되 고 있다. 수동가입자망이란 전화국에서 가입자 근처까지는 단일 광섬유를 활용하고 원격지(Remote node)에서 각 가입 자로는 수동분배기를 이용하여 분기한 뒤 개별 광섬유를 통 해 전달되는 방식을 취한다. 이로 인해 수동가입자망은 광섬 유의 효율적 사용은 물론 원격지에 전기를 필요로 하지 않기 때문에 유지 비용이 적게 드는 장점을 가지고 있다. 이러한 수동 가입자망은 그림 3 과 같이 다시 시간분할방식과 파장 분할방식으로 구별 된다.

시간분할방식 수동가입자망(TDM-PON: Time Division Multiplexing-Passive Optical Network)의 경우 가입자로의 하향신 호는 수동 광파워분배기로 나뉘어 브로드캐스팅되는 방식을 취한다. 상향신호의 경우 각 가입자별로 할당된 시간영역에 서 상향 통신을 전송한다. 이러한 TDM-PON의 경우 전화국 에서 하나의 광송수신기로 많은 수의 가입자를 수용할 수 있 고 가입자의 사용상태에 따라 대역폭 할당을 유연하게 할 수 있는 장점이 있으나 사용자 수가 늘어날 경우 대역폭이 줄어 들고 하향신호가 모든 가입자에게 분배되기 때문에 보안상 의 취약점을 가지고 있다.

파장분할방식 수동가입자망(WDM-PON: Wavelength Division Multiplexing-Passive Optical Network)의 경우 서로 다른 파 장의 $\mathrm{WDM}$ 채널 신호를 원격지에서 배열도파로 회절격자
(AWG: Arrayed Waveguide Grating)를 이용하여 각 가입자 별로 파장 분기를 통하여 통신하는 방식을 취한다. WDM$\mathrm{PON}$ 은 각 가입자별로 별개의 파장으로 통신하기 때문에 실 제로는 점대점 방식의 통신을 취하게 되어 가입자가 광송수 신기가 가지는 최대 대역폭의 사용이 가능하며 보안 측면에 서 우수한 장점이 있다. 하지만 각 가입자별로 다른 종류의 파장을 가진 광원을 준비해야 하므로 비용이 상승하는 단점 이 있다. 현재 비용적인 이점으로 대부분의 광가입자망이 TDM-PON 방식으로 구성되어 있다.

광가입자망의 표준화는 ITU-T, IEEE 등 국제표준화 기구 에서 이루어지고 있으며 전송 프로토콜에 따라 $\mathrm{GPON}$ (Gigabit Passive Optical Network), EPON(Ethernet Passive Optical Network) 등으로 나뉘어 TDM-PON의 표준화가 진 행되었으며 가입자망의 대역폭 증가에 따라 WDM-PON의 표준화도 시작되어 현재 활발히 진행 중이다. $\mathrm{EPON}$ 의 경우 한국, 일본, 중국 등에서 많이 포설되어 있으며 GPON은 미 국, 유럽 등에서 주로 사용된다. 현재 $\mathrm{EPON}$ 은 $1 \mathrm{Gbps}$ 통신 이, GPON은 $2.5 \mathrm{Gbps}$ 통신이 이루어지고 있으며 양쪽 기술 모두 $10 \mathrm{Gbps}$ 로 통신 속도를 업그레이드 하기 위한 광소자 및 기타 부품 개발이 거의 완료되어 있는 상황이다. TDM$\mathrm{PON}$ 에서 사용되는 광부품의 경우 프로토콜에 관계없이 동 작 파장과 동작 속도가 가장 중요한 파라메터가 된다. 핵심 광부품으로는 직접 변조형 DFB(Distributed Feedback) 레이 저, PIN-PD, 광분배기 등이 있고 $10 \mathrm{Gbps}$ 가입자망의 경우 변조 속도 향상에 따른 전송거리 확보를 위해 전계흡수형 변 조기 집적 $\mathrm{DFB}$ 레이저(EML: Electro-absorption Modulator integrated Laser)가 광송신기에 적용되고 있으며 광수신기의 경우 수신감도 향상을 위한 아발란치 광검출기(APD: Avalanche Photo Diode) 등이 사용된다. 광가입자망의 경우 송신, 수신에 서로 다른 광섬유를 사용하는 기존 광통신망과 는 다르게 하나의 광섬유를 통한 양방향 통신 방식을 택하고 있어 상향, 하향 신호가 각각 다른 파장을 가진다. 이러한 이 유로 상하향 파장을 분리하는 파장 필터와 이를 포함하는 효 율적인 패키징 기술이 중요하다. 경우에 따라 CATV용 파장 신호가 더해지거나 $10 \mathrm{G}$ 가입자망이 동시에 적용될 경우 3 가 지 파장을 수용해야 하는 Triplexer가 구성된다. 가장 보편적 으로 TO 캔을 이용한 패키지 방식이 주고 사용되고 있다. 하이브리드 또는 모노리식 집적형 구도도 연구, 개발이 이루 어져 일부 광부품 업체를 통해 상용화가 되었으나 상대적으 로 높은 비용으로 점유율이 낮은 편이다. 그림 4(a)는 10G-EPON용으로 개발된 TO 방식의 OLT(Optical Line Terminal)용 Triplexer TOSA를 나타내고 있다. 하향 송신부 는 서로 다른 파장을 갖는 $1.25 \mathrm{Gbps}$ 와 $10 \mathrm{Gbp}$ 의 신호를 송 신할 수 있는 TO 캔 송신기 2개와 상향 신호를 수신하는 $\mathrm{TO}$ 캔 수신기로 구성되어 있으며 2개의 박막필터를 이용하 여 파장을 분리하는 방식을 취한다. 그림 4(b)는 이를 적용한 10G-EPON용 XFP 트랜시버를 나타낸다.

$\mathrm{WDM}-\mathrm{PON}$ 의 경우 가입자 수만큼 서로 다른 파장의 광원 이 필요하기 때문에 설치 및 유지 비용이 상대적으로 높다. 


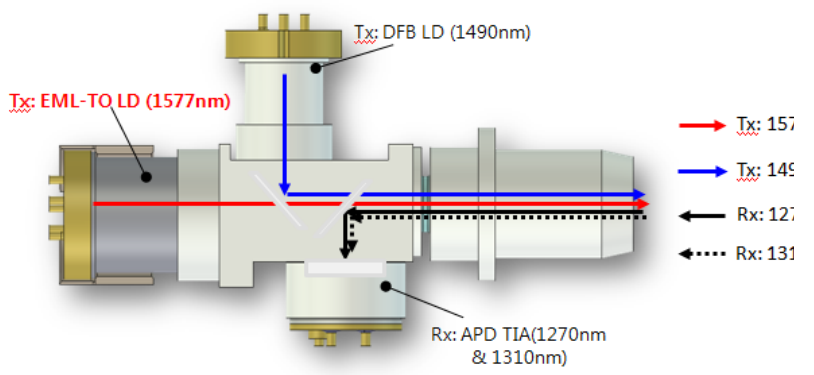

(a)

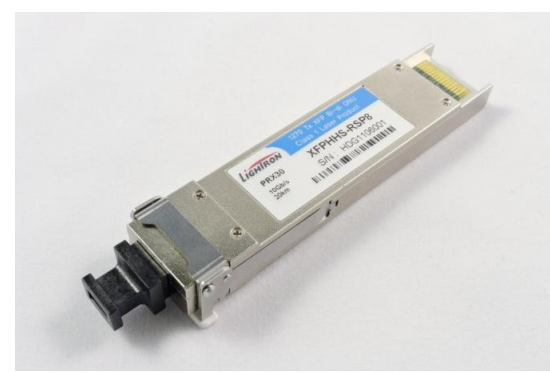

(b)

FIG. 4. (a) Schematic diagram of triplexer TOSA, (b) Photograph of a 10G-EPON XFP transceiver.

이러한 문제점을 해결하기 위해 저가의 파장 무의존(Colorless) 광원 개발에 대한 연구가 활발히 진행되고 있다. 대표적인 방법으로는 외부 씨앗광원(Seed light)을 주입하는 방식인데 비교적 저가인 FP-LD나 반사형 광증폭기(RSOA: Reflective Semiconductor Optical Amplifier)에 씨앗 광원을 주입하는 방식이 개발되어 상용화 되었으나 여전히 비용문제로 보급 은 저조한 편이다. 씨앗광원 주입 기반의 WDM-PON 방식은 파장을 제어하는 장치가 별도로 필요하지 않는 장점을 가지 나 외부광원이 별도로 필요하며 FP-LD나 RSOA의 변조 대 역폭에 제한이 있어 주로 $2.5 \mathrm{Gbps}$ 이하의 WDM-PON에 활 용된다. ${ }^{[3,4]} 10 \mathrm{Gbps}$ 이상의 WDM-PON 구축을 위해서 광신 호를 증폭하는 $\mathrm{SOA}$ 와 신호 변조를 위한 흡수전계형 변조기 가 단일 집적된 REAM-SOA에 대한 연구가 진행 중이다. ${ }^{[5,}$ 6] 또 다른 $\mathrm{WDM-PON}$ 구현 방식은 파장가변형 광원을 사용하 는 방식으로 이 경우는 독립적인 광원 구성으로 단순한 구조 로 시스템 구성이 가능하나 파장가변 광원의 저가화가 관건 이다. 최근에는 폴리머 도파로 기반의 저가형 직접 변조 파 장가변광원을 이용한 $\mathrm{WDM}-\mathrm{PON}$ 이 $2.5 \mathrm{Gbps}$ 급까지 개발 되 었고 $10 \mathrm{Gbps}$ 에 대한 연구가 진행 중이다. ${ }^{[7,8,9]}$

WDM-PON의 경우 국내 기술이 세계적으로 선도적인 위 치에 있으며 다양한 기술들이 개발 되었다. 그림 5(a)는 10 Gbps용 REAM-SOA로, $20 \mathrm{~km}$ 이상 전송이 가능하며 전송 속 도와 전송 거리를 늘리기 위한 연구가 진행 중이다. 그림 5(b)는 $2.5 \mathrm{Gbps}$ 동작속도를 갖는 폴리머 회절격자 기반의 외부-공진형(ECL: External Cavity Laser) 파장가변 광원을 나타낸 것이다. 폴리머의 높은 열광학계수를 이용하여 회절 격자 부분에 형성된 히터에 전류주입을 통한 작은 온도 변화

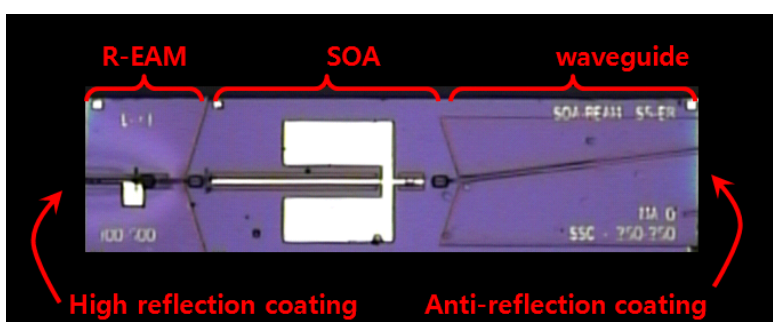

(a)

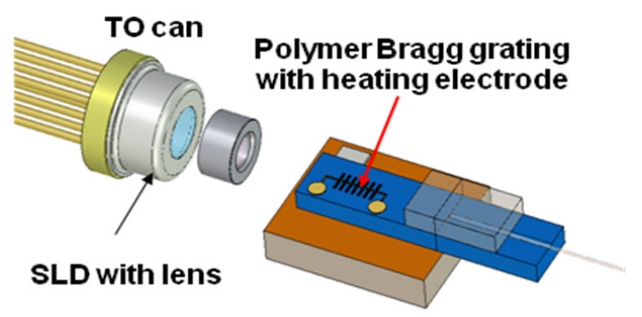

(b)

FIG. 5. (a) Photograph of REAM-SOA, (b) Schematic diagram of tunable PLC-ECL.

로도 넓은 범위의 파장 이동이 가능하다는 장점이 있다. 현 재 $2.5 \mathrm{Gbps}$ 의 동작 속도를 갖는 트랜시버가 이를 기반으로 상용화 진행 중에 있으며 $10 \mathrm{Gbps}$ 변조 가능한 저가형 파장 가변 광원에 대한 연구도 진행 중에 있다. $\mathrm{WDM-PON}$ 은 가 격 경쟁력 측면에서 어려움을 가지고 있으나 가입자망의 대 역폭 요구가 지속적으로 증가함에 따라 적용 가능성이 점차 높아지고 있으며 가격 경쟁력 확보를 위한 저가형 광원 개발 을 통해 그 도입 시기를 당기려는 노력이 진행 중이다.

$\mathrm{WDM}-\mathrm{PON}$ 에서는 원격지에서 각 가입자로의 파장 분기가 필요하며 이를 위해 $\mathrm{AWG}$ 가 사용되는데 실외의 열악한 환 경에서도 사용 가능한 온도 무의존형 $\mathrm{AWG}$ 가 필요하다. 일 반적으로 $\mathrm{AWG}$ 는 온도에 따라 중심파장이 변하는데 온도 무의존형 $\mathrm{AWG}$ 는 온도변화에 따른 파장 변화를 보상하기 위해 입력부 위치를 온도에 따라 자동으로 조정하는 기계적 인 장치를 이용하는 방법과 광 경로상에 홈을 만들어 실리카 와 반대의 열광학특성을 갖는 실리콘 레진을 채워 보상하는 방법이 가장 많이 사용되고 있다. ${ }^{[10]}$

가입자망에 대한 지속적인 대역폭 증가 전망에 따라 ITU$\mathrm{T}$ 에서는 차세대 광가입자망 기술(NG-PON2)에 대한 표준화 작업을 진행하고 있으며 이를 위해 각국의 통신사업자의 요 구사항을 조사하고, 이를 만족할 수 있는 광가입자망 기술들 에 대해 검토하였다. NG-PON2의 주요 요구사항을 살펴보면 총 전송 용량 $40 \mathrm{G}$, 가입자당 $1.25 \mathrm{Gbps}$, 전송거리 $40 \mathrm{~km}$, 수용 가입자 수 64가입자 이상 수용 등으로 이러한 요구사항 을 만족하는 기술로 TWDM-PON, WDM-PON, OFDM-PON 및 하이브리드 PON 등이 후보 기술로 제안되었고 2012년 초 TWDM-PON이 채택되었다. ${ }^{[1]}$

TWDM-PON은 기존 TDM-PON에서 파장 수를 확대한 개 념으로 초기 $\mathrm{WDM}$ 4채널을 채택하고 있으며 WDM-PON과 


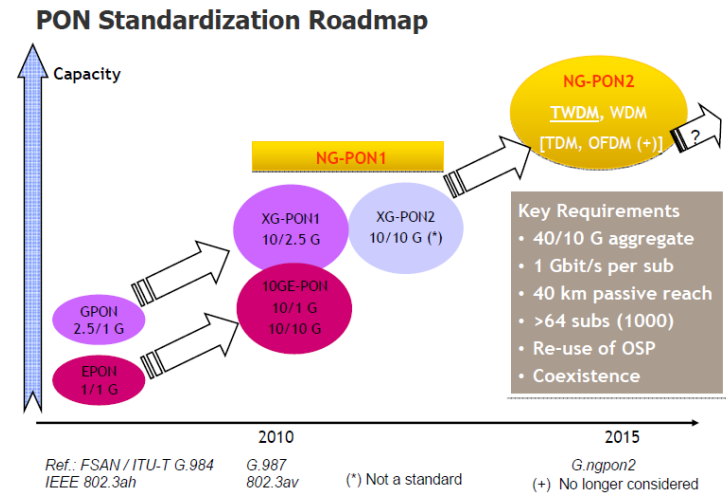

(a)

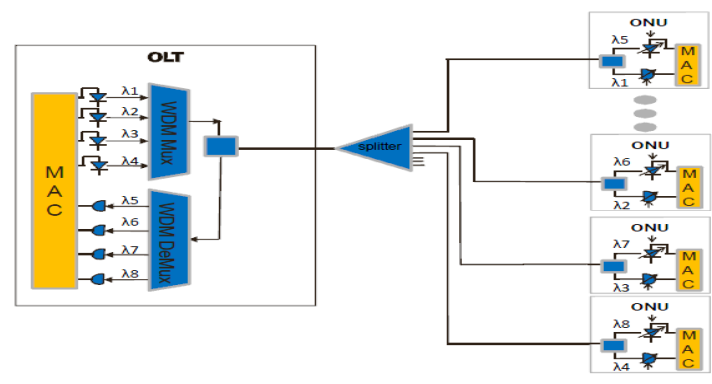

(b)

FIG. 6. (a) PON standardization roadmap, (b) Schematic configuration of TWDM-PON.

는 달리 원격지에서 광파워분배기를 사용하므로 기존 가입 자망에 거의 변화를 주지 않으면서도 대역폭 증가가 가능하 며 네트워크 상황에 따라 유연하게 대처할 수 있는 장점이 있다. 이러한 TWDM-PON 시스템 구성에서 핵심 부품은 가 입자측에서 파장 선택을 위해 저가의 가입자용 파장가변 광 원 및 수신기를 개발하는 것이다.

향후에도 광가입자망의 트래픽은 지속적으로 증가할 것으 로 예측되며 이를 수용하기 위해서 보다 진보된 가입자망 기 술에 대한 연구가 진행 중이다. 현재는 WDM 기반의 광가입 자망 구성이 유력하나 순수 WDM-PON보다는 하이브리드 형태의 조합이 될 가능성이 매우 높다. OFDM(Orthogonal Frequency Division Multiplexing)-PON은 현재 장거리망에 도입되고 있는 코히어런트 통신을 가입자망에 응용하기 위 한 기술로 현재는 디지털 신호 처리기 개발 비용 문제, 시스 템의 복잡성 등 여러 가지 난관을 가지고 있지만 장거리 통 신에서의 기술발전에 따라 유망한 기술로 평가받고 있다. ${ }^{[12]}$

\section{III. 매트로 통신용 광부품}

매트로망은 일반적으로 도시 간을 연결하는 통신망으로 장 거리 통신의 점대점(point-to-point) 통신 방식에서 벗어나 다 점대다점(multi point-to-multi point) 방식의 통신이 필요하다. 매트로망에서는 전송 대역폭을 늘리기 위해 파장이 다른 여 러 채널의 신호를 하나의 광섬유를 통해 전달하는 DWDM

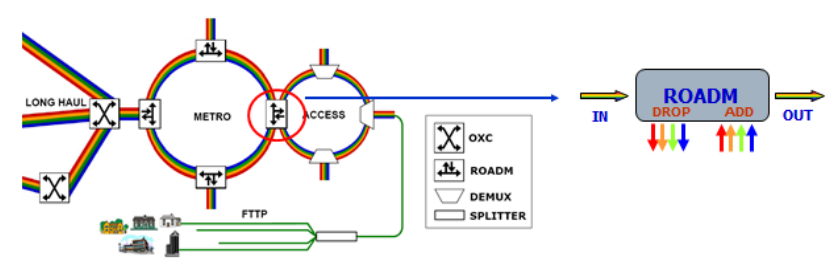

FIG. 7. Position of ROADM in optical network and its role.

(Dense Wavelength Division Multiplexing) 방식을 채택하고 있으며 각 노드에서는 필요한 신호를 추출(Drop)해 내고 노 드에서 생산된 신호를 삽입(Add)하는 방식(OADM: Optical Add-Drop Multiplexing)으로 신호를 전달한다. 현재 가입자 망에서 시작한 트래픽 증가를 수용하기 위해서 통신 사업자 에 의한 매트로망의 증설 및 고도화 작업이 지속적으로 진행 되고 있다.

기존의 매트로망에서는 DWDM의 여러 전달 파장 중 특정 노드에서 추출/삽입될 신호에 특정 파장을 미리 할당하는 고 정형 방식, 즉 Fixed OADM(F-OADM) 방식이 사용되었다. $\mathrm{F}-\mathrm{OADM}$ 에서는 각 노드에서 파장이 고정된 필터를 이용하 여 정해진 파장의 신호를 추출하고 파장이 고정된 레이저를 이용하여 정해진 파장의 새로운 신호를 삽입하였다. 이러한 F-OADM 방식의 가장 큰 문제점은 특정 노드의 트래픽 증 감에 따라 할당 파장을 증가 또는 감소시켜야 할 경우 노드 상에서 필요한 하드웨어를 직접 설치 및 조정하는 작업을 수 행해야 한다. 이러한 방식은 음성 위주의 안정적 트래픽에서 는 안정적 운용이 가능하였으나 현재와 같이 데이터 위주의 통신량의 변화가 급격한 상황에서는 효율적 운용이 불가능 하다.

이러한 문제점을 해결하기 위해 추가 채널의 추출/삽입 뿐 아니라 기존 채널의 수정작업도 원격지에서 수행할 수 있는 장치를 Reconfigurable OADM(R-OADM)이라 한다. ${ }^{[13]}$ 이러 한 원격지 제어를 수행하기 위해서는 원격지에서 제어가 가 능한 스위치 및 가변광감쇄기 등 핵심 광소자와 이의 제어 기술의 개발이 핵심 요소이다. ROADM의 도입으로 매트로 망의 유연성 및 효율성 증대를 통하여 운용 비용의 절감을 가져올 수 있기 때문에 2000년대 중반부터 미국, 일본을 중 심으로 도입되기 시작하였으며 국내에서도 현재 KT가 ROADM 시스템을 도입하고 있는 중이다.

한편 $\mathrm{OADM}$ 에서는 출입되는 신호의 경로 수를 일반적으 로 자유도라 표현하는데 일반적인 링구조의 매트로망에 사 용되는 $\mathrm{OADM}$ 의 자유도는 2이다. 증가하는 트래픽의 수용 과 보다 효율적인 망 운용을 위해서는 기존 링타입의 매트로 망 구조에서 메쉬형태로 발전할 것으로 예측되는데 이러한 메쉬 네트워크에서는 자유도 3 이상을 지원하는 ROADM이 필요하다. ROADM 시스템은 파장 의존성, 자유도, 파장 선 택성 등에 따라 기능상 몇 가지로 분류할 수 있으며 각 분류 에 따라 다른 기술이 사용된다. 이러한 ROADM의 기능상의 차이 및 발전은 궁극적으로 DWDM 매트로망의 효율성 증가 를 목적으로 하므로 다양한 구도의 ROADM 시스템이 함께 
혼재되어 쓰여질 가능성이 높다.

자유도 2의 링 네트워크에 사용되는 iPLC(integrated Planar Lightwave Circuit) 기반의 ROADM의 경우 핵심소자로 신호 의 통과 또는 삽입 결정을 위한 $2 \times 1$ 스위치 어레이와 통과 또는 삽입되는 채널간의 광세기 조정을 위한 가변광감쇄기, 통과 또는 삽입된 채널의 다중화를 위한 평탄한 필터 특성을 가지는 AWG 등이 있다. ${ }^{[14]}$ PLC 기반의 광스위치 구성에서 는 실리카 기반의 PLC 소자의 경우 마흐젠더 간섭계 구조를 이용하여 스위치를 구현하는데 실리카의 열광학 계수가 크 지 않아 전력소모가 큰 편이다. 이를 극복하기 위해 전극 및 도파로 주변에 트렌치를 형성하여 전력소모를 줄이는 방법 이 개발되고 있다. 한편 폴리머의 경우 상대적으로 높은 열 광학계수를 활용하여 간섭현상을 이용하지 않고도 적은 전 력소모를 가지는 디지털 스위치와 가변광감쇄기 제작이 가 능하다. ${ }^{[15]}$ 또한 iPLC형 ROADM의 경우 DWDM 신호의 역 다중화 및 다중화에 AWG가 사용되는데 DWDM 신호가 메 트로망에 전송될 때 많은 수의 ROADM 노드를 거쳐야 하기 때문에 그림 8(b)와 같이 통과 대역폭이 넓은 Flat-top 특성 을 갖는 $\mathrm{AWG}$ 의 사용이 필수적이다.

네트워크가 복잡해짐에 따라 메쉬 구조의 네트워크가 도입 되면 높은 자유도의 수용이 가능한 ROADM 장치가 필요하

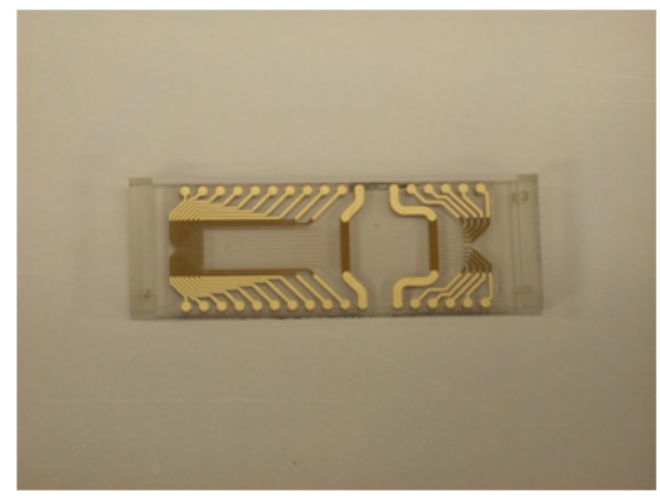

(a)

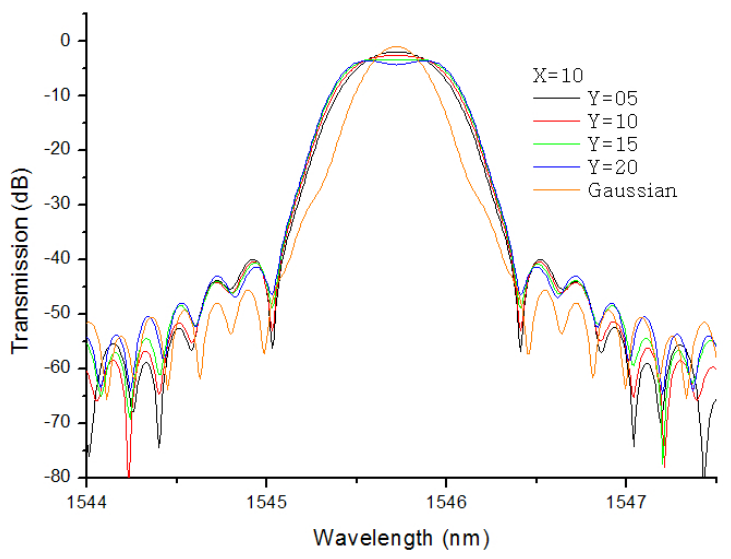

(b)

FIG. 8. (a) Photograph of polymer based 10 channel VOA/ Switch array, (b) Transmission spectra of flat-top AWG.
며 어떤 파장이든 임의의 방향으로 보내줄 수 있는 기능을 수행하는 파장 선택 스위치(WSS: Wavelength Selective Switch) 를 필요로 한다. ${ }^{[16]}$ 파장 선택 스위치는 하나의 입력단에 입 사된 DWDM 신호를 N개의 출력단에 자유로운 파장 조합으 로 분산시킬 수 있는 장치를 말한다. 파장 선택 스위치는 입 력 파장을 분기 또는 결합하는 $\mathrm{WDM}$ 다중화/역다중화기 (Mux/Demux)와 파장별로 경로 변경이 가능한 스위칭 소자 가 핵심 부품이다. 평면 도파로 기반의 파장 선택 스위치 기 술의 개발도 이루어지고 있으나 ${ }^{[17]}$ 높은 삽입 손실로 인해 일반적으로 벌크 광학계를 이용한 파장 선택 스위치가 상용 화되고 있다. 벌크 광학계를 이용한 파장선택 스위치에는 입 력 파장의 분기/결합에는 벌크 회절격자가 사용되고 스위칭 소자로는 MEMS(Microelectromechanical System), LC(Liquid Crystal), LCoS(Liquid Crystal on Silicon), DLP(Digital Light Processing) 등 다양한 기술이 사용되고 있다. ${ }^{[18,}{ }^{19]}$ 그림 9 는 파장 선택 스위치의 개략적인 구도와 스위칭 구도를 나타낸다.

ROADM은 트래픽 용량 증가에 따른 네트워크 발전에 따 라 함께 진화하고 있다. 그림 10 은 ROADM의 다양한 구도 를 나타낸다. 현재 링네트워크 구조에서는 그림 $10(\mathrm{a})$ 와 같 은 $\mathrm{iPLC}$ 기반 ROADM이 주로 사용되고 있고 메쉬네트워크 구조에서는 WSS가 적용된 ROADM이 사용된다. 통신 용량 의 증가에 따라 메쉬 구조가 복잡해질수록 한 노드에서 서로 다른 방향에서 오고 가는 신호의 파장 대역에서의 충돌이 일 어날 가능성이 높아진다. 3 세대 ROADM에서는 이러한 충돌

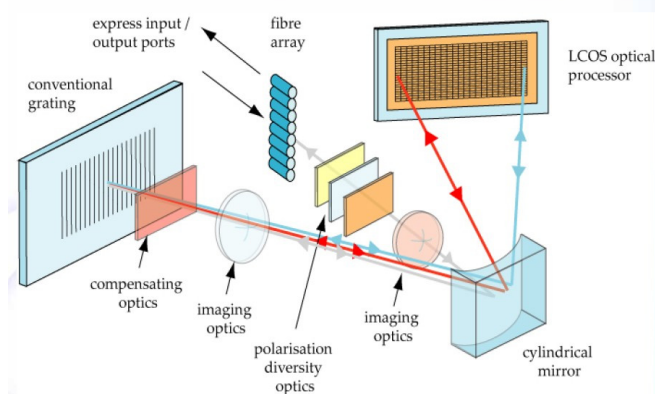

(a)
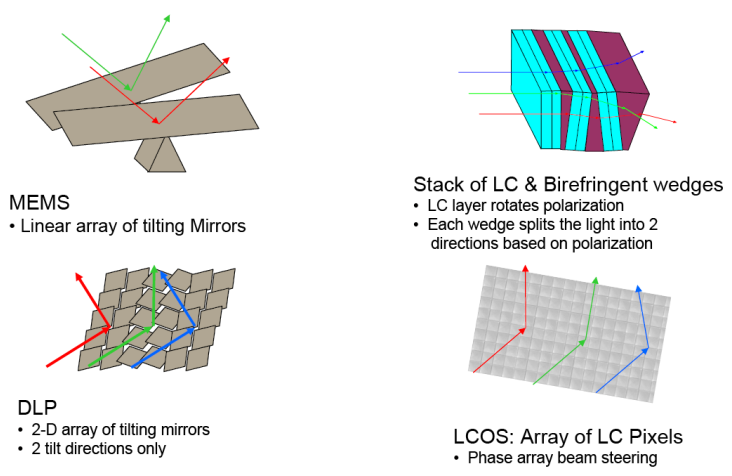

(b)

FIG. 9. (a) Schematic diagram of wavelength selective switch, (b) Various switching engines of WSS. 


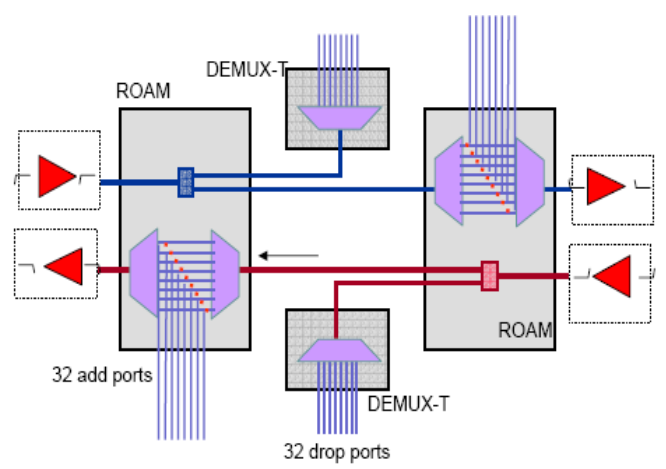

(a)

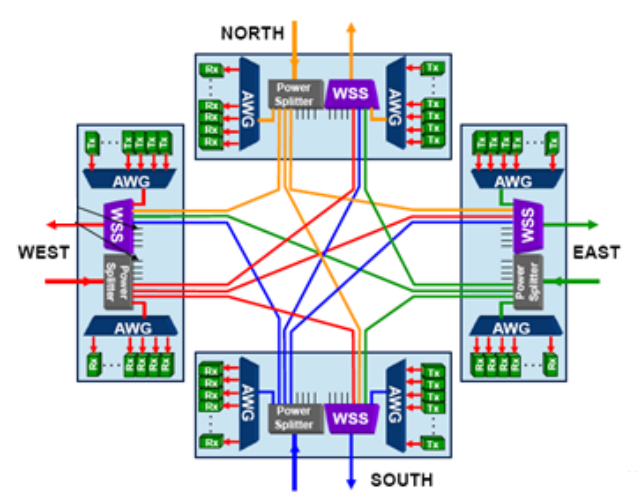

(b)

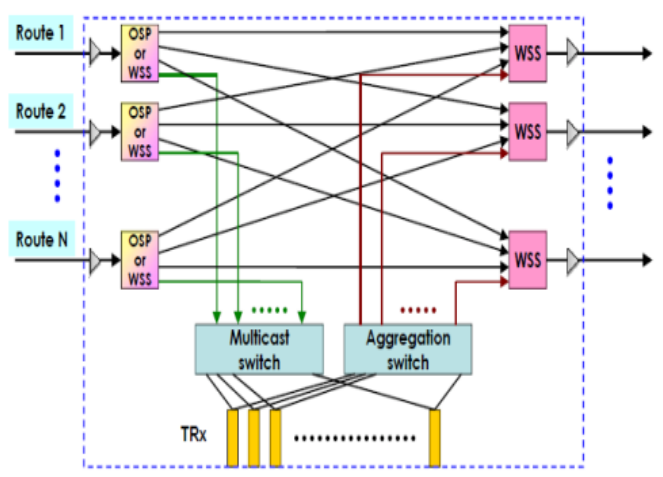

(c)
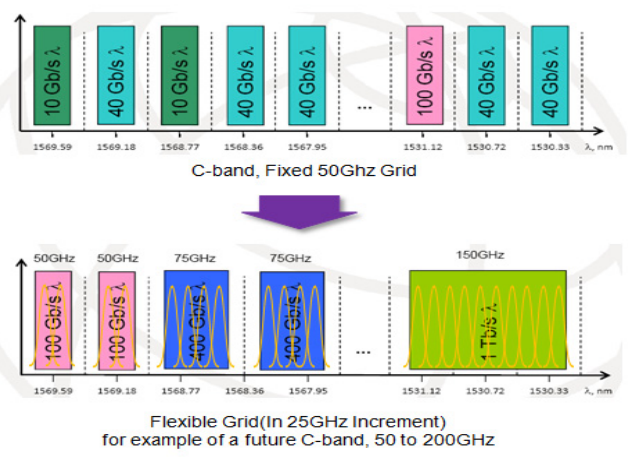

(d)

FIG. 10. (a) Diagram of iPLC-type ROADM, (b) Diagram of Multi-degree ROADM, (c) Diagram of CDC ROADM using Multicast Switch, (d) Illustration of flexible spectrum architecture.
을 막는 기능(Contentionless)을 포함시키며 이를 위한 핵심 부품이 $\mathrm{MxN} \mathrm{WSS}$ 의 도입이다. ${ }^{[18]}$ 그림 $10(\mathrm{c})$ 에서와 같이 노 드에서 광송수신기를 하나의 뱅크로 묶고 효과적인 입출력 을 위해 $\mathrm{MxN} \mathrm{WSS}$ 를 배치하면 새로운 경로 설정 시 기존 설정 파장에 무관하게 신호처리가 가능하다. 이러한 $\mathrm{MxN}$ $\mathrm{WSS}$ 를 구현하기 위한 방법으로 PLC기반의 멀티캐스트 스 위치의 개발이 진행되고 있다. 멀티캐스트 스위치를 사용하 면 기존 설정에 관계없이 임의의 포트에서 임의의 파장을 임 의의 방향으로 보낼 수 있어 Contentionless ROADM 구성이 가능하다. ${ }^{[20]}$ 한편 데이터 변조 방식 및 데이터 변조 속도에 따라 신호가 가지는 파장 선폭이 달라짐에 따라 그림 $10(\mathrm{~d})$ 과 같이 기존의 고정된 $\mathrm{DWDM}$ 채널 간격 $(50$ 또는 $100 \mathrm{GHz})$ 에서 자유롭게 중심파장 및 채널 간격을 조절할 수 있는 플 렉시블 그리드(Flexible grid) 도입이 논의되고 있다. ROADM 에서도 이러한 기능의 수용을 위해서 $\mathrm{LCoS}$ 기술을 이용하여 플렉시블 그리드 수용이 가능한 파장 선택 스위치의 개발이 이루어지고 있다. ${ }^{[21]}$ 플랙시블 그리드 수용이 가능한 ROADM 스위치가 적용되면 변조속도에 따라 채널 간격의 유연한 배 분을 통해 전송 스팩트럼 효율을 약 $30 \%$ 정도 증가시킬 수 있을 것으로 기대하고 있다.

최근 들어 트래픽 패턴의 급격한 변화 수용과 클라우드 환 경에 적응하기 위해 전달평면과 제어평면을 분리하는 $\mathrm{SDN}$ (Software Defined Network)의 도입이 논의되고 있다. ${ }^{[22] ~ ㅈ ㅣ ㄴ ~}$ 정한 $\mathrm{SDN}$ 구현을 위해서는 물리계층까지 소프트웨어에 의 해 자유롭게 경로 설정, 망 관리 등이 가능하게 할 수 있는 시스템의 도입이 요구되고 있으며 이러한 기능의 수행에 필 요한 핵심장치가 ROADM이다. 이러한 $\mathrm{SDN}$ 구현을 위한 $\mathrm{ROADM}$ 은 앞서 설명한 어떤 파장이든(Colorless), 어떤 방향 으로도(Directionless), 기존 경로 설정에 무관하게(Contentionless) 스위칭이 가능한 $\mathrm{CDC}$ 기능과 더불어 스팩트럼 효율을 높이 기 위해 Flexible grid를 수용할 수 있는 기술이 되어야 한다. $\mathrm{CDC}-\mathrm{F}$ 기능을 갖는 ROADM의 도입으로 네트워크의 효율 성을 크게 향상시킬 수 있어 ROADM의 도입은 점차 확대될 것으로 전망된다.

한편 DWDM을 이용한 매트로망의 운용에서 각 노드에는 다량의 ITU 규격을 만족하는 파장을 가진 여러 개의 광원이 필요한데 이를 파장 가변 광원으로 대체할 경우 재고량 감소 로 인한 운용비용 절감이 가능한 장점이 있어 파장 가변 광 원에 대한 다양한 연구가 이루어지고 있다. ${ }^{[23]}$ 파장 가변 광 원은 기본적으로 광대역 광원과 파장 선택 필터를 이용하여 특정 파장만을 선택적으로 발진하게 하는 구조이다. 통신용 파장 가변 광원의 경우 소형화, 저전력화가 함께 구현되어야 하며 매트로용 파장 가변 광원의 경우 필요에 따라 변조기를 집적하는 구조로 개발된다. 현재 통신용으로 개발되는 파장 가변 광원의 경우 크게 3 가지 방식으로 나뉠 수 있다. 첫번 째는 $\mathrm{DFB}$ 어레이를 이용하는 방식으로 $\mathrm{DFB}$ 의 좁은 파장 가변 범위를 극복하기 위해 DFB 어레이를 제작하여 넓은 범 위의 파장 가변 영역를 구현하는 방식이다. ${ }^{[24]}$ 두번째는 외부 공진기를 이용하는 방법으로 광대역 이득을 갖는 반도체 광 
원과 넓은 범위의 파장 변화가 가능한 필터를 조합하여 파장 가변 광원을 구성하는 방식이다. ${ }^{[25]}$ 마지막으로 넓은 파장 가 변 범위를 구현하기 위해 주기가 조금 다른 반사형 필터를 이득매질 양쪽에 두어 버니어 효과를 이용하여 파장 가변 범 위를 확보하는 방법이다. ${ }^{[26-28]}$ 첫번째 방식의 예로 그림 11(a) 는 여러 채널의 DFB 어레이를 멀티모드 간섭계를 이용하여 결합시켜 단일집적형 파장가변광원을 제작한 방식이고 그림 $11(\mathrm{~b})$ 는 MEMS 거울을 이용하여 필요한 $\mathrm{DFB}$ 와 공진기를 구 성해 파장 가변을 하는 방식이다. 두번째 방식의 예로 그림 $11(\mathrm{c})$ 는 광대역 광원과 외부 회절 격자를 조합하여 특정 파 장을 발진시키는 구조로 $\mathrm{MEMS}$ 구동계를 이용하여 파장 가 변을 하는 구조이고 그림11(d)는 광대역 광원과 결합된 폴리 머 도파로에 회절격자를 새긴 뒤 히터를 이용해 온도변화에 따른 굴절률 변화를 통한 회절격자 반사파장의 변화를 이용 해 파장 가변 광원을 구성하는 방법이다. 마지막 방식으로 그림 11(e)는 주기가 조금 다른 부분회절격자(SG: Sampled Grating)를 이득 매질 양쪽에 두어 전류인가에 따른 굴절률 변화와 버니어 효과에 의한 파장 변화 범위 확대로 넓은 범

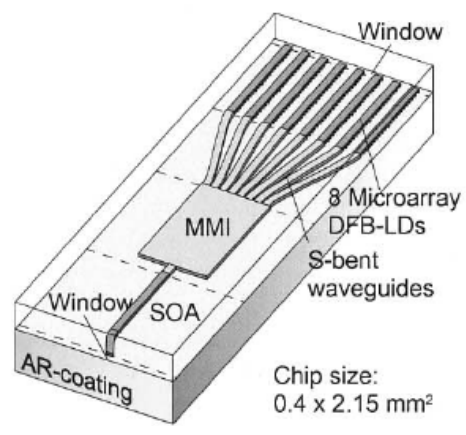

(a)

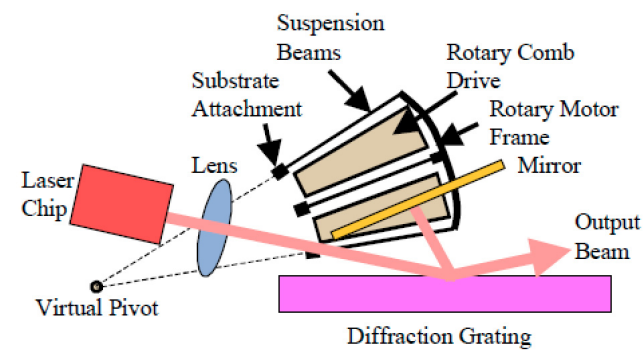

(c)

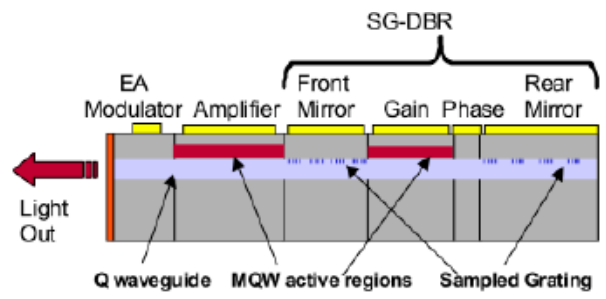

(e)
위의 파장 가변이 가능하도록 하는 구조이다. 그림 11(f)는 유사한 구조를 부분회절격자 $\mathrm{Y}$ 모양으로 나누어 제어의 효율 성을 높인 구조이다. 이와 같이 여러 가지 구조의 파장 가변 광원에 대한 연구가 지속적으로 이어져 왔고 아직도 다양한 연구가 이루어지고 있다. $10 \mathrm{Gbps}$ 이하의 경우 주로 광변조 기가 집적된 파장 가변 광원을 이용하여 기존 트랜시버 대비 크기 및 전력소모가 크게 줄어든 XFP(10 Gbps(X) Form-factor Pluggable) 트랜시버가 향후 시장을 지배할 것으로 예측된다. 컴퓨터 간의 통신 프로토콜로 출발한 이더넷(Ethernet) 기 술은 인터넷의 보급으로 가장 보편적인 통신 프로토콜로 발 전하여 현재는 대부분의 통신이 이더넷을 사용하고 있다. 이 더넷의 표준은 IEEE 802.3에서 이루어지고 있으며 기가비트 이더넷 표준화(1998년)에 이어 10기가비트 이더넷 표준(2002 년)을 제정하였다. 그리고 2010년 6월에는 거리별로 40G, $100 \mathrm{G}$ 까지 표준화가 완료된 상태이고 금년부터 $400 \mathrm{G}$ 에 대한 표준화가 추진될 예정이다. $40 / 100 \mathrm{G}$ 이더넷에 대한 거리별 표준화 현황을 살펴보면 표 1 과 같다. ${ }^{[2]}$ 단거리 통신에서는 $850 \mathrm{~nm}$ 대역의 VCSEL과 다채널 광섬유를 이용한 병렬 통

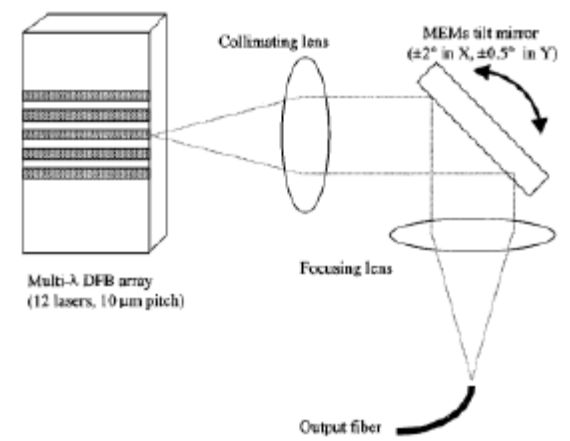

(b)

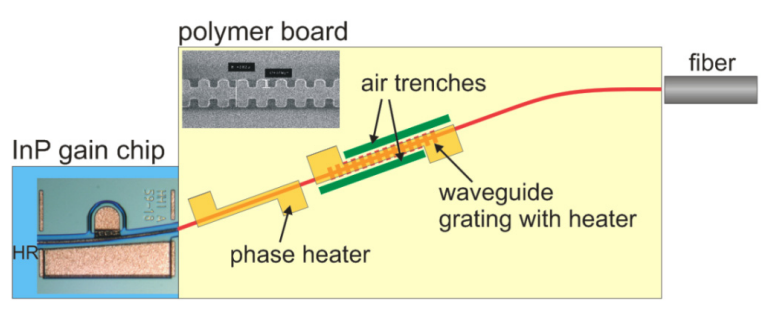

(d)

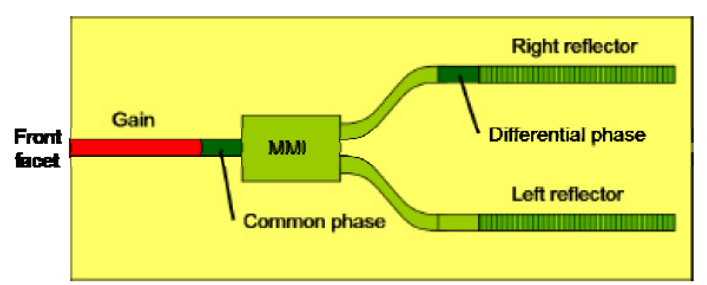

(f)

FIG. 11. Examples of tunable lasers types: (a) Monolithic selectable DFB array with MMI, (b) Hybrid selectable DFB array with MEMS mirror, (c) Tunable external cavity diode laser with MEMS actuator (d) Polymer based tunable PLC-ECL, (e) SG-DBR laser, (f) Modulated grating $\mathrm{Y}$ laser. 
TABLE 1. 40/100G 이더넷 표준화 현황

\begin{tabular}{|c|c|c|}
\hline & 40GbE & 100GbE \\
\hline $1 \mathrm{~m}$ B.P & 40GBASE-KR4 & \\
\hline $7 \mathrm{~m}$ Copper Cable & 40GBASE-CR4 & 100GBASE-CR10 \\
\hline $100 \mathrm{~m}$ MMF & 40 GBASE-SR4 & 100GBASE-SR10 \\
\hline $10 \mathrm{~km}$ SMF & 40GBAE-LR4 & 100GBASE-LR4 \\
\hline $40 \mathrm{~km}$ SMF & & 100GBASE-ER4 \\
\hline
\end{tabular}

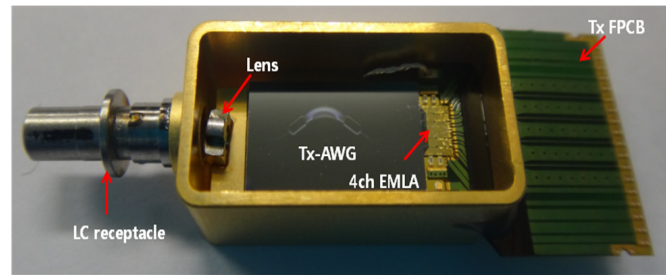

(a)

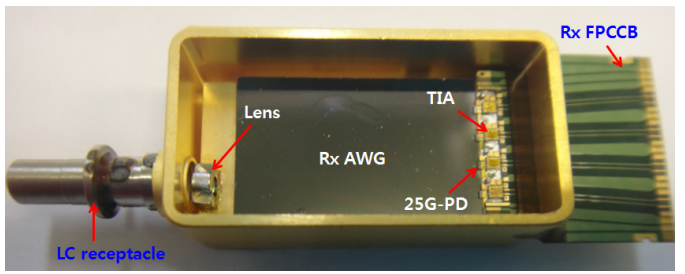

(b)

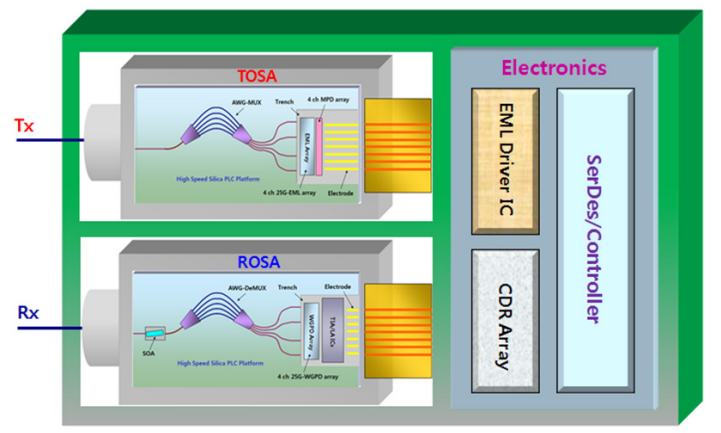

(c)

FIG. 12. (a) $100 \mathrm{G}$ TOSA module, (b) $100 \mathrm{G}$ ROSA module, (c) Schematic diagram of $100 \mathrm{G}$ Ethernet transceiver.

신 방식을 채택하였고 비교적 장거리인 $10,40 \mathrm{~km}$ 통신에서 는 $1.3 \mathrm{um}$ 대역의 WDM 기술과 단일모드 광섬유를 이용한 전송방식이 표준화되었다.

클라이언트 네트워크란 일반적으로 이더넷을 기반으로 하 는 기업망을 의미하였으나 근래에 들어 통신이 음성전달 기 반에서 이더넷 기반의 데이터 전달 위주로 발전함에 따라 넓 은 의미에서는 전달망으로 전해지기 위해 집속되는 모든 데 이터 네트워크를 의미한다. 특히 Google, Facebook 등 인터 넷기반의 서비스 업체의 대용량 데이터 센터의 건설에 따라 데이터 센터 내 또는 데이터 센터 사이의 트래픽은 매우 빠 른 속도로 증가하고 있다. 이러한 대용량 트래픽의 수용을 위해서는 초소형, 저전력 소모의 고속 클라이언트용 트랜시 버 개발이 필요하다.

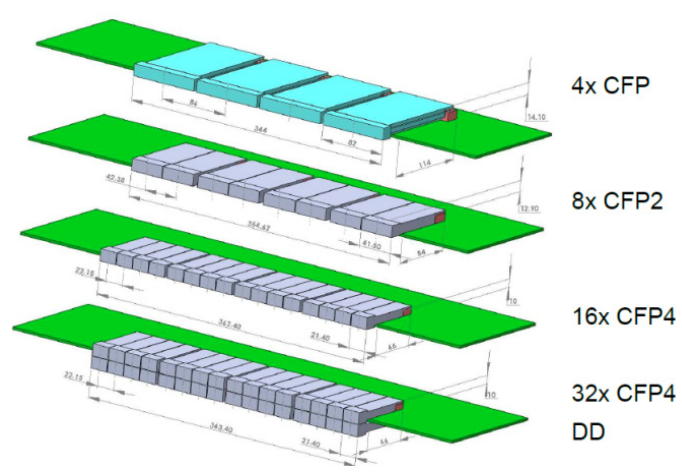

FIG. 13. Comparison of CFP module density in linecard installation for different form factors.

데이터 센터의 특성상 막대한 양의 데이터를 처리해야 하 기 때문에 하나의 라인카드가 가지는 데이터 처리 용량이 매 우 중요하다. 제한된 라인 카드의 면적에서 처리 용량을 늘 리기 위해서는 트랜시버가 차지하는 면적의 감소와 발열량 을 줄이는 것이 중요하다. 따라서 클라이언트용 트랜시버는 고속화되면서도 소형화, 저전력화를 구현하는 연구가 진행되 고 있다.

$100 \mathrm{G}$ 클라이언트 트랜시버는 그림 12에서 보듯이 표준화 규격에 따라 4채널의 광원, 광원들을 결합시키는 $\mathrm{AWG}-$ MUX로 구성된 광송신기(TOSA: Transmitter Optical SubAssembly)와 4채널의 입력신호를 분리시키는 AWG-DEMUX 와 4채널의 PD 어레이로 구성된 광수신기(ROSA: Receiver Optical Sub-Assembly)로 구성되어 있다.[30] 그리고 레이저 들을 구동하기 위한 드라이버 IC와 수신부 데이터를 복원하 기 위한 CDR(Clock and Data Recovery) 어레이, SerDes, 제 어용 $\mathrm{MCU}, \mathrm{FPGA}$ 등 전자소자가 트랜시버에 포함된다.

$10 \mathrm{~km}$ 이상의 $100 \mathrm{G}$ 이더넷 신호의 전송에는 단일 모드 광 섬유를 매개체로 $1.3 \mathrm{um}$ 대역의 $800 \mathrm{GHz}$ 채널 간격을 가진 $25 \mathrm{Gbps}$ 속도의 4채널이 사용된다. 이를 위해 광원으로는 EML이 사용되고 있고 수신기에는 PIN-PD가 사용된다. $40 \mathrm{~km}$ 전송의 경우 $1.3 \mathrm{um}$ 대역의 광섬유 손실을 보상하기 위해 반도체 광증폭기(SOA: Semiconductor Optical Amplifier)가 사용된다. 현재 CFP(100 Gbps(C) Form-factor Pluggable) 형태 의 트랜시버가 Finisar, JDSU, Oclaro 등을 통해 상용화되어 있다. 하지만 앞서 언급한 바와 같이 클라이언트용 트랜시버 의 가장 중요한 요소인 소형화, 저전력화를 위해 차기 버전 의 트랜시버 개발이 필요하며 전력 소모를 줄이기 위해 광원 을 직접 변조 레이저(DML: Direct Modulation Laser)로 대체 하고 일부 전자 소자를 라인 카드로 옮기는 연구가 진행 중 이다. 그림 13은 트랜시버 타입에 따른 라인카드상의 장착 예상도를 보여주며 CFP2, CFP4 타입의 트랜시버를 적용하 면 장착밀도를 2 배, 4 배 또는 8 배까지 증가시킬 수 있다. ${ }^{[31]}$

\section{IV. 장거리 통신용 광부품}

장거리 전송망의 경우 최우선으로 고려해야 할 부분은 전 
송 속도와 전송 거리 확보에 있다. 장거리 전송은 대역폭 확 대를 위해 매트로망과 마찬가지로 DWDM 방식을 채택하고 있으며 점대점 통신 방식을 사용한다. 광섬유는 막대한 대역 폭을 제공하지만 근래에 들어 대용량 트래픽의 폭증으로 광 통신에서도 전송 효율을 높이는 작업이 필요하게 되었다. ${ }^{[32]}$ 광통신은 디지털 신호의 전송을 위해 일반적으로 빛 세기 변 조 기술(OOK modulation)을 이용하여 ' 1 ', ' 0 '의 신호 전송 을 해왔다. 이러한 세기 변조 방식(ASK: Amplitude shift key) 은 $10 \mathrm{Gbps}$ 전송까지는 최고의 기술로 각광받아 왔으나 전 송속도가 높아짐에 따라 광섬유에서 발생하는 각종 분산과 비선형 특성으로 위상 변조 방식 (PSK: Phase Shift Key)이 선호되고 있다. 또한 통신 용량의 증가에 따라 DWDM 전송 에서 채널당 변조 속도(Baud rate)의 단순 증가는 전자 소자

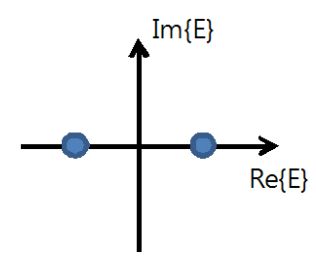

BPSK

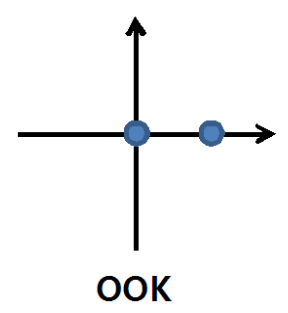

(a)

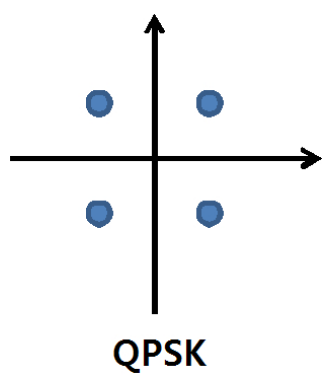

(b)

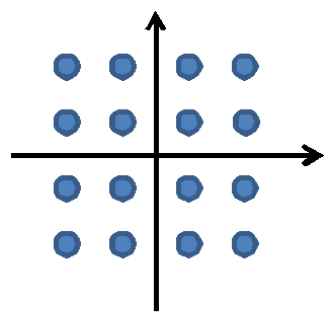

16-QAM

(c)

FIG. 14. The constellation diagrams for (a) OOK and BPSK, (b) QPSK, (c) 16-QAM.
의 물리적 속도의 한계, 고주파 신호선 제작 및 패키징의 어 려움 등으로 심볼당 비트 수를 증가하는 방향으로 발전하고 있다. 이를 위해 그림 14 에서와 같이 크기 변조와 위상 변조 를 결합하여 하나의 심볼로 전송할 수 있는 비트 수를 늘리 는 여러 가지 진보된 변조 방식이 도입되고 있다. 예를 들어 $\mathrm{OOK}$ 변조 방식의 경우 하나의 심볼로 1 비트의 신호만 전송 할 수 있지만 16-QAM(Quadrature Amplitude Modulation) 변 조 방식의 경우 하나의 심볼로 4 비트의 신호 전송이 가능하 다. 따라서 동일한 변조 속도를 사용하여 4 배의 통신 속도 증가를 가져 올 수 있다.

한편 광은 전자기파의 일종으로 세기뿐 아니라 위상 정보 도 가지고 있다. 광통신은 전송신호의 검출 방법에 따라 직 접 검출(Direct Detection) 방식과 코히어런트 검출(Coherent Detection) 방식으로 구분할 수 있다. 빛의 세기뿐만 아니라 위상, 편광 및 주파수 등을 변조하여 신호를 전송하는 코히 어런트 광통신 기술은 1980년대 후반 수신기 감도증가 및 이에 따른 전송거리 증가를 위해 초기 연구가 이루어졌다. ${ }^{[33]}$ 이후 WDM 전송 기술의 발전으로 관심에서 멀어졌다가 근 래에 들어 통신 속도 향상에 따른 전송 거리 확대 및 효율 증대의 필요성에 따라 다시 각광을 받기 시작했다.

직접검출 방식은 광검출기에 도달하는 광세기를 전류로 변 환하는 방식으로 이 과정에서 위상 정보는 사라지게 된다. 반면 코히어런트 검출 방식에서는 송신광과 동일한 또는 유 사한 광원과 간섭계를 이용하여 세기 정보뿐 아니라 위상정 보도 검출할 수 있는 방식이다. 따라서 코히어런트 검출 방 식의 경우 직접 검출 방식에 비해 훨씬 복잡한 구조와 신호 처리 기술을 필요로 하지만 장거리 고속 통신에서 발생하는 광섬유의 분산, 비선형 등의 문제와 복잡한 변조 방식 처리 의 우월성 때문에 장거리 통신에 적용되기 시작했다.

최근의 코히어런트 광통신 기술의 발전에 힘있어, 차세대 대용량 광통신 분야에 있어서 기술혁신이 이루어지고 있다. 2012년 ITF는 $100 \mathrm{Gbps}$ 광통신에서 여러 가지 변조 방식 중 OSNR(Optical Signal-to-Noise Ratio, 광신호잡음비) 특성과 스펙트럼 효율 측면에서 우수한 이중편광 직교위상천이 변 조 방법(DP-QPSK(Dual Polarization Quadrature Phase Shifting $\mathrm{Key})$ )을 채택하였다. DP-QPSK 방식은 QPSK 변조를 통해 한 개의 심볼이 2 비트의 신호를 생성할 수 있고 이중편광을 이용하여 심볼당 4 비트를 전달할 수가 있어서 $25 \mathrm{G}$ 의 보드 속도(baud rate)로 $100 \mathrm{G}$ 의 데이터를 전송하는 것이 가능하 게 되었다. DP- QPSK 코히어런트 통신을 구현하기 위해서 는 그림 15 에서와 같이 송신기를 구성하는 핵심부품은 광분 배기(BS: Beam splitter), 직교위상변조기(quadrature modulator), 편광변환기(polarization rotator) 및 편광결합기 (PBC: Polarization Beam Combiner)이다. 수신기 분야에서는 편광분리기(PBS: Polarization Beam Splitter), 90도 광하이브리 드(90 deg optical hybrid) 및 밸런스 광검출기(balanced detector)가 핵심 광부품이다. ${ }^{[34]}$

한편 송신기에는 신호 전송을 위한 고출력 파장가변광원, 수신기에는 코히어런트 광검출을 위한 국부 발진기 용도의 


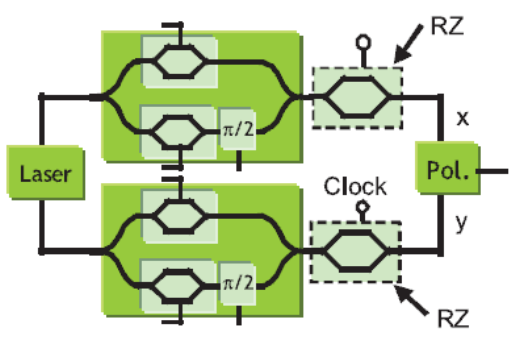

(a)

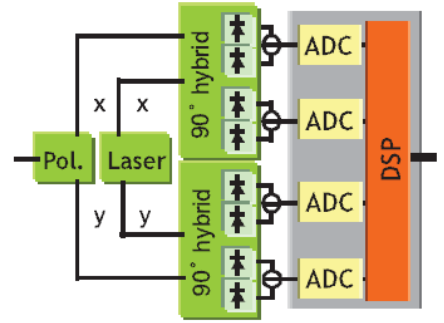

(b)

FIG. 15. Schematic setup of the opto-electronic components of (a) a transmitter, (b) a receiver for DP-QPSK format.

파장 가변 광원이 포함된다. 코히어런트 통신에 사용되는 파 장가변광원의 경우 매트로에서 사용되는 파장가변광원과 마 찬가지로 C-band 또는 L-band를 포함하는 파장 가변 범위와 함께 $16 \mathrm{dBm}$ 의 높은 출력광 세기와 수백 $\mathrm{kHz}$ 의 낮은 선폭 을 확보하는 것이 필수적이다. 이는 코히어런트 통신에서 이 중 편광을 사용하기 때문에 높은 출력이 송신기에 필요할 뿐 아니라 수신기의 경우 국부 발진기의 광세기가 클수록 수신 감도가 높아지기 때문이다. 또한 위상 잡음을 최소화하기 위 해서는 좁은 선폭을 가진 광원이 필요하다. 현재 장거리 통 신용 파장가변광원은 주요 업체에서 상용화 되고 있으나 코 히어런트 통신을 위한 고출력과 낮은 선폭을 동시에 만족하 는 파장가변광원은 연구가 진행 중에 있다.

직교위상변조기는 주로 마흐젠더 변조기(Mach-Zehnder Interferometer)가 사용된다. 마흐젠더 변조기의 양단은 전압 을 가했을 때 굴절률이 변하는 전기광학효과를 이용하여 높 은 속도의 변조 신호를 발생시키며 주요 물질은 전기광학효 과가 큰 $\mathrm{LiNbO}_{3}$ 또는 반도체 양자우물을 이용한다. $\mathrm{LiNbO}_{3}$ 의 경우 구동전압이 비교적 높고 크기가 큰 편이지만 신뢰성 있는 변조 특성을 제공하고 특히 낮은 삽입손실을 가지고 있 어 상용제품의 대부분을 차지한다. 변조 방식이 복잡해짐에 따라 여러 개의 마흐젠더 간섭기가 집적되어야 하기 때문에 실리카 광도파로와 $\mathrm{LiNbO}_{3}$ 도파로가 하이브리드 결합된 구 조의 직교위상변조기가 개발되어 상용화되고 있다. ${ }^{[36]}$

반면 $\mathrm{InP}$ 기반의 마흐젠더 간섭기는 작은 크기와 낮은 구 동전압의 장점을 가지고 있지만 공정 수율이 낮고 높은 삽입 손실과 파장 의존성 등의 단점으로 상용화가 미흡한 편이 다. ${ }^{[37,38]}$ 하지만 $100 \mathrm{G} \mathrm{DP-QPSK}$ 및 그 이상의 동작속도를 위해서는 보다 더 높은 수준의 집적화가 요구되어 반도체 기 반의 전기광학변조기에 대한 연구가 꾸준히 진행 중이며

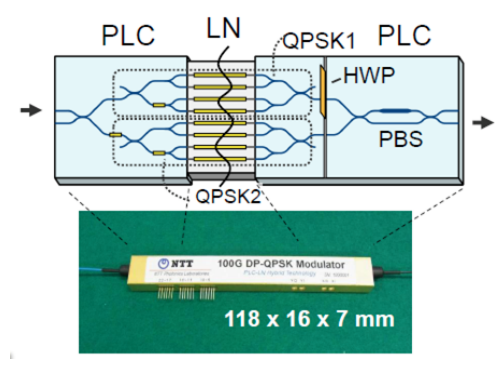

(a)
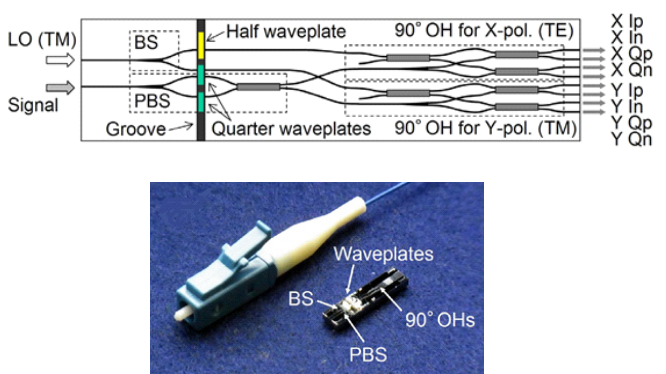

(b)

FIG. 16. (a) Configuration (top) and photograph (bottom) of the DP-QPSK modulator, (b) Configuration (top) and (b) photograph of DP-QPSK receiver.

Infinera의 경우 자체 개발한 완전집적형 송신기를 시스템에 적용하고 있다. 이 밖에도 $\mathrm{GaAs}$ 기반의 직교위상간섭기와 실 리콘 포토닉스 기반의 직교위상변조기도 개발되어 코히어런 트 광모듈 소형화 및 저가화를 대비하고 있다. ${ }^{[39,40]}$

앞서 기술한 바와 같이 광통신에서 광검출기를 하나만 사 용할 경우 신호전류는 입사된 빛의 세기(전기장의 제곱)에 비례하여 신호의 위상 성분은 사라지게 된다. 코히어런트 광 통신에서는 국부발진기와 광하이브리드 및 밸런스 광검출기 를 통해서 신호의 크기 성분뿐 아니라 위상 성분도 검출하게 된다. 코히어런트 광수신을 위해서는 수신기에 입력된 광의 위상 성분 검출을 위해 $2 \times 4$ 구조를 갖는 90 도 광하이브리드 가 필요하며 \pm 5 도 이내의 출력단 위상차를 요구한다. 코히어 런트 광수신기에 사용되는 밸런스 광검출기는 광원 잡음을 상쇄시킬 수 있고 큰 DC 신호 가운데 작은 신호 변화를 검 출할 수 있는 장점을 가진다. 밸런스 광검출기의 중요한 특 성 변수로 공통모드잡음제거율(CMRR: Common Mode Rejection Ratio)을 들 수 있으며, 이 때 CMRR은 두 PD 간의 특성 차 이 뿐만 아니라 입사 신호의 경로차이에서 발생하는 편차에 의해서도 나빠지는 변수이므로 최적의 특성을 얻기 위해서 는 세심한 주의가 필요하다. 벌크 광학계를 이용한 편광분리 기, 광하이브리드 등이 먼저 상용화 되었으나 평면 도파로를 이용한 광하이브리드에 대한 연구가 진행되어 광검출기가 하 이브리드 집적된 일체형 코히어런트 광검출기가 개발되었 다. ${ }^{[41,42]}$ 코히어런트 광검출기에서도 폴리머 플랫폼을 이용 한 광검출기, ${ }^{[43]} \mathrm{InP}$ 단일 집적형 광검출기, 실리콘 포토닉스 를 이용한 광검출기 등 다양한 결과들이 발표되고 있다. ${ }^{[44]}$

그림 16은 NTT에서 개발된 코히어런트용 DP-QPSK용 광 
송신기와 광수신기의 모습을 보여주고 있다. 광송신기의 경 우 실리카 광도파로와 $\mathrm{LiNbO}_{3}$ 도파로가 하이브리드 결합된 구조로 편광 회전기, 편광 결합기 일체를 PLC 도파로상에 구현하였다. 광수신기의 경우에도 편광분리기, 편광회전기, 90 도 광하이브리드가 일체형으로 구성되었으며 광검출기가 하이브리드 집적되는 구조를 가진다. 이러한 코히어런트 광 통신을 위한 광부품의 장점은 디지털 신호 처리기의 도입으 로 동일한 광부품을 활용하여 변조방식의 변화가 가능하다 는 점이다. $100 \mathrm{Gbps}$ DP-QPSK 변조에 사용되는 동일한 구 도의 광변조기와 수신기를 활용하여 16-QAM 변조 방식을 활용하면 $200 \mathrm{Gbps}$ 신호 생성이 가능하다. 2개의 파장(DC: Dual Carrier)을 이용하여 $400 \mathrm{Gbps}$ 신호를 전송하는 기술이 개발되었으며 ${ }^{[4]}$ 이와 같은 DC DP-16QAM 기술이 $400 \mathrm{Gbps}$ 전송의 표준으로 사용될 전망이다.

코히어런트 광트랜시버 구성을 위해서는 광부품 이 외에도 여러 가지 전자소자가 필요한데 특히 광수신부에는 광수신 기에서 나온 신호 처리를 위한 디지털신호처리기(DSP: Digital Signal Processor) 기술이 매우 중요하다. DSP를 이용하여 분 산 보상 및 클락 추출 등 신호 보정 및 복원이 가능하며 현 재 $100 \mathrm{G}$ 코히어런트용 $\mathrm{DSP}$ 는 미국, 일본에서 각각 $\mathrm{ASIC}$ 기술 개발에 성공했다.

$100 \mathrm{Gbps}$ 코히어런트 광트랜시버의 경우 현재 $\mathrm{OIF}$ 에서 $178 \times 127 \mathrm{~mm}^{2}$ 의 크기와 $80 \mathrm{~W}$ 이내의 전력 소모를 갖는 것 으로 MSA가 이루어져 상용제품이 출시되기 시작했으나 향 후 통신 용량의 증가를 수용하기 위해 $\operatorname{CFP}\left(140 \times 82 \mathrm{~mm}^{2},<32\right.$ W) 타입의 크기, 더 나아가 CFP2 $\left(106 \times 42 \mathrm{~mm}^{2},<12 \mathrm{~W}\right)$ 타 입의 크기로 진화해야 할 것으로 전망된다. 이러한 모듈 소 형화 구현을 위해서는 특히 광부품의 소형화가 필요하며 이 를 위해서는 여러 가지 물질을 기반으로 한 광집적회로(PIC: Photonic Integrated Circuit) 기술의 개발이 진행 중이다.

앞서 기술한 SDN 기술이 광전달망에 활용되기 위해 필요 한 광송수신 기술은 유한한 파장 대역폭을 효율적으로 사용 하기 위하여 대역폭 가변 및 파장 가변 기술, 서비스 품질 요구 조건에 따른 전송거리를 가변할 수 있는 기능이 요구되 고 있다. 전속속도, 전송거리가 고정된 기존의 광트랜시버와 달리 코히어런트 광부품과 디지털 신호처리를 이용하면 소 프트웨어 제어로 필요에 따라 전송거리, 전송속도 및 스펙트 럼 효율성 등을 조절할 수 있는 유연한 광트랜시버 개발이 가능하다. ${ }^{[4]}$

최근 통신용량은 연 $40 \%$ 이상의 급격한 증가를 보이고 있 어 머지않아 DWDM 기술과 코히어런트 통신 도입에 의한 스팩트럼 사용 효율 향상만으로는 통신량 증가를 수용하기 힘든 시기가 도래할 것으로 전망되고 있다. 이를 극복하기 위해 다중 모드 광섬유를 이용한 다중 모드 통신과 다중 코 어 광섬유를 이용한 공간 분할 방식의 광통신 기술이 개발되 고 있으며 이에 필요한 광부품에 대한 연구도 진행 중이 다. ${ }^{[47,}{ }^{48]}$ 다중 모드 전송 방식은 몇 개의 모드를 지원하는 광 섬유를 이용하여 각각의 신호를 서로 다른 모드로 여기시켜 전송하는 방식으로 서로 다른 모드에 신호를 여기하고 다시

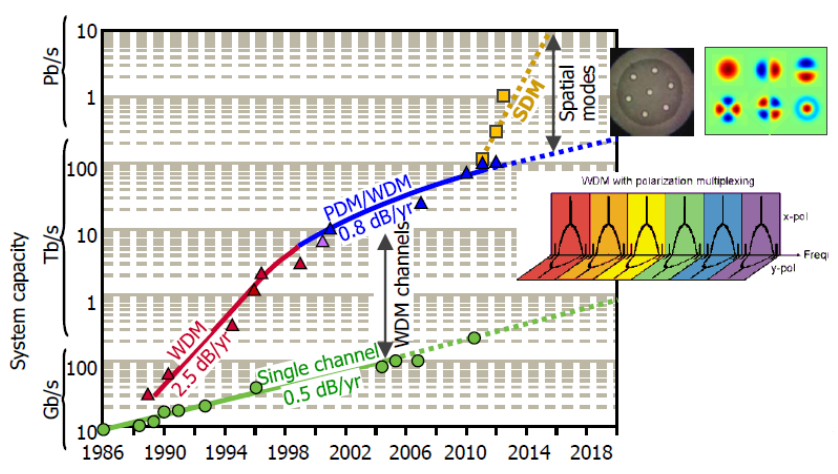

FIG. 17. Progress of system capacity.

수신단에서 각 모드를 효율적으로 분리해 내기 위한 연구가 진행 중이다. 공간 분할 광통신은 다중 코어를 가진 광섬유 를 이용하여 통신 대역폭을 확장하는 방식인데 다중 코어에 신호 입출력, 다중 코어 광섬유 증폭기 개발, 다중 코어 광섬 유간의 간섭 문제 등을 해결하기 위한 연구가 진행 중이다. 이를 적용하면 그림 17 에서 보듯이 포화상태에 도달하고 있 는 전송용량 증가율을 획기적으로 높일 수 있을 것으로 기대 하고 있다. 하지만 두 가지 방식 모두 대역폭의 증가를 가져 올 수는 있지만 기존 광섬유와의 호환성이 부족하고 새로운 종류의 광섬유 포설이라는 큰 문제를 가지고 있어 향후 상용 시스템에 적용될 지는 조금 더 지켜보아야 한다.

\section{V. 결 론}

앞서 살펴본 바와 같이 광통신용 광부품은 계층 구조에 따 라 전송 거리, 전송 속도뿐 아니라 코스트, 크기, 전력 소모 등을 고려하여 최적화된 광부품의 개발이 진행되고 있다. 인 터넷의 보급으로 확대되기 시작한 광통신은 오늘날 스마트 기기 및 클라우드 서비스 보급 등으로 더욱 빠르게 성장하고 있으며 향후에도 그 증가 폭은 더욱 커질 것으로 예측되고 있다. 이에 따라 전송 방식의 경우 시간 분할 방식에서 파장 분할 방식이 도입되었고 현재는 코히어런트 통신 방식이 도 입되고 있으며 새로운 전송 방식에 대한 연구가 진행 중이 다. 적용범위도 기존 중장거리 통신뿐 아니라 데이터 전송량 확대에 따라 가입자망, 데이터 센터, 모바일 통신망 및 단거 리 광인터커넥션까지 그 범위를 넓혀 가고 있다. 이러한 광 통신 대역폭 확대와 광통신 적용 범위 확대에 따라 광통신은 또 다른 부흥기를 준비하고 있으며 이러한 다양한 요구 사항 을 충족시키기 위해 광통신 부품은 고속화, 집적화, 저전력 화를 통해 더욱 발전해 갈 것으로 전망된다.

\section{References}

1. R.-J. Essiambre, G. Kramer, P. J. Winzer, G. J. Foschini, and B. Goebel, "Capacity limits of optical fiber networks," J. Lightwave Technol. 28, 662-701 (2010).

2. P. J. Winzer and R.-J. Essiambre, "Advanced optical 
modulation formats," Proc. IEEE 94, 952-985 (2006).

3. J. S. Jeong, H.-K. Lee, and C.-H. Lee, "1.25 Gb/s operation at $50-\mathrm{GHz}$ channel spacing based on intensity noise suppression of wavelength-locked Fabry-Perot laser diode," IEEE Photon. Technol. Lett. 21, 602-604 (2009).

4. A. D. McCoy, P. Horak, B. C. Thomsen, M. Ibsen, and D. J. Richardson, "Noise suppression of inchorehent light using a gain-saturated SOA: Implications for spectrum-sliced WDM systems," J. Lightwave Technol. 23, 2399-2049 (2005).

5. E. K. MacHale, G. Talli, P. D. Townsend, A. Borghesani, I. Lealman, D. G. Moodie, and D. W. Smith, "Extended-reach PON employing $10 \mathrm{~Gb} / \mathrm{s}$ integrated reflective EAM-SOA," in Proc. ECOC (Brussels, Belgium, Sep. 2008), CD, paper Th.2.F.1.

6. H.-S. Kim, D. C. Kim, K.-S. Kim, B.-S. Choi, and O-K. Kwon, "10.7 Gb/s reflective electroabsorption modulator monolithically integrated with semiconductor optical amplifier for colorless WDM-PON," Opt. Express 18, 23324-23330 (2010).

7. K.-H. Yoon, S. H. Oh, K. S. Kim, O. K. Kwon, D. K. Oh, Y.-O. Noh, and H.-J. Lee, "2.5-Gb/s hybridly-integrated tunable external cavity laser using a superluminescent diode and a polymer bragg reflector," Opt. Express 18, 5557-5561 (2010).

8. K. Prince, T. B. Gibbon, R. Rodes, E. Hviid, C. I. Mikkelsen, C. Neumeyr, M. Ortsiefer, E. Ronneberg, J. Rosskopf, P. Ohlen, E. I. De Betou, B. Stoltz, E. Goobar, J. Olsson, R. Fletcher, C. Abbott, M. Rask, N. Plappert, G. Vollrath, I. T. Monroy, "GigaWaM-next-generation WDM-PON enabling gigabit per-user data bandwidth," J. Lightwave Technology 30, 1444-1454 (2012).

9. B.-S. Choi, S. H. Oh, K. S. Kim, K.-H. Yoon, H. S. Kim, M.-R. Park, J. S. Jeong, O. K. Kwon, J.-K. Seo, H.-K. Lee, and Y. C. Chung, "10-Gb/s direct modulation of polymerbased tunable external cavity lasers," Opt. Express 20, 20368-20375 (2012).

10. S. Kamei, "Recent progress on athermal AWG wavelength multiplexer," in Proc. OFC/NFOEC (San Diego, CA, USA, March 2009), CD, paper OWO1.

11. H. Nakamura, "NG-PON2 technologies," in Proc. OFC/ NFOEC (Anaheim, CA, USA, March 2013), CD, paper NTh4F.5.

12. D. Qian, J. Hu, J. Yu, P. Ji, L. Xu, Ting Wang, M. Cvijetic, and T. Kusano, "Experimental demonstration of a novel OFDM-a based 10Gb/s PON architecture," in Proc. ECOC 2007 (Berlin, Germany, 2007), CD, paper 5.4.1.

13. B. P. Keyworth, "ROADM subsystems and technologies," in Proc. OFC/NFOEC (March 2005), CD, paper OWB5.

14. J.-U. Shin, Y.-T. Han, S.-P. Han, S.-H. Park, Y. Baek, Y.-O. Noh, and K.-H. Park, "Reconfigurable optical add-drop multiplexer using a polymer integrated photonic lightwave circuit," ETRI Journal 31, 770-777 (2009).

15. Y.-T. Han, J. U. Shin, S.-H. Park, S.-P. Han, Y. Baek, C.-H. Lee, Y.-O. Noh, H.-J. Lee, and H.-H. Park, "Fabrication of 10-channel polymer thermo-optic digital optical switch array," IEEE Photon. Technol. Lett. 21, 1556-1558 (2009).

16. R. Shankar, M. Florjańczyka, T. J. Halla, A. Vukovicb, and H. Hua, "Multi-degree ROADM based on wavelength selective switches: Architectures and scalability," Opt. Commun. 279, 94-100 (2007).

17. T. Goh, T. Kitoh, M. Kohtoku, M. Ishii, T. Mizuno, and A. Kaneko, "Port scalable PLC-based wavelength selective switch with low extension loss for multi-degree ROADM/ WXC," in Proc. OFC/NFOEC (San Diego, CA, USA, Feb. 2008), CD, paper OWC6.

18. P. Colbourne and B. Collings, "ROADM switching technologies," in Proc. OFC/NFOEC 2011 (Los Angeles, CA, USA, 2011), CD, paper OTuD1.

19. T. Strasser and J. Wagener, "Wavelength-selective switches for ROADM applications," IEEE J. Select. Topic Quantum Electron. 16, 1150-1157 (2010).

20. T. Watanabe, K. Suzuki, and T. Takahashi, "Silica-based PLC transponder aggregators for colorless, directionless, and contentionless ROADM," in Proc. OFC/NFOEC 2012 (Los Angeles, CA, USA, March 2012), CD, paper OTh3D.1.

21. S. Frisken, G. Baxter, D. Abakoumov, H. Zhou, I. Clarke, and S. Poole, "Flexible and grid-less wavelength selective switch using LCOS technology," in Proc. OFC/NFOEC 2011 (Los Angeles, CA, USA, 2011), CD, paper OTuM3.

22. B. Collings, "New devices enabling software-defined optical networks," IEEE Communications Magazine March, 66-71 (2013).

23. L. Coldren, G. Fish, Y. Akulova, J. Barton, L. Johansson, and C. Coldren, "Tunable semiconductor lasers: A tutorial," J. Lightwave Technol. 22, 193-202 (2004).

24. H. Hatakeyama, K. Kudo, Y. Yokoyama, K. Naniwae, and T. Sasaki, "Wavelengthselectable microarray light sources for wide-band DWDM applications," IEEE J. Select. Topics Quantum Electron. 8, 1341-1348 (2002).

25. J. D. Berger, Y. Zhang, J. D. Grade, H. Lee, S. Hrinya, and H. Jerman, "Widely tunable external cavity diode laser based on a MEMS electrostatic rotary actuator," in Proc. OFC 2001 (Anaheim, CA, USA, 2001), CD, paper TuJ2.

26. L. A. Coldren, "Monolithic tunable diode lasers," IEEE J. Select. Topics Quantum Electron. 6, 988-999 (2000).

27. A. J. Ward, D. J. Robbins, G. Busico, E. Barton, L. Ponnampalam, J. P. Duck, N. D. Whitbread, P. J. Williams, D. C. Reid, A. C. Carter, and M. J. Wale, "Widely tunable DS-DBR laser with monolithically integrated SOA: Design and performance," IEEE J. Select. Topics Quantum Electron. 11, 149-156 (2005).

28. J. O. Wesstrom, S. Hammerfeldt, J. Buus, R. Siljan, R. Laroy, and H. de Vries, "Design of a widely tunable modulated grating y-branch laser using the additive vernier effect for improved super-mode selection," in Proc. Semiconductor Laser Conference 2002 (Garmisch-Partenkirchen, Germany, Sep. 2002), pp. 99-100.

29. http://www.ieee802.org/3/ba/. 
30. Y. Baek, Y. T. Han, C. W. Lee, D. H. Lee, O. K. Kwon, J. W. Shin, S. H. Park, and Y. A. Leem, "Optical components for 100G ethernet transceivers," in Proc. OECC 2012 (Busan, Korea, 2012), pp. 218-219.

31. C. Cole, "Next generation CFP modules," in Proc. OFC/ NFOEC 2012 (Los Angeles, CA, USA, March 2012), CD, paper NTu1F.1.

32. P. J. Winzer, "High-spectral-efficiency optical modulation formats," J. Lightwave Technol. 30, 3824-3835 (2012).

33. L. Kazovsky, G. Kalogerakis, and W. Shaw, "Homodyne phase-shift-keying systems: Past challenges and future opportunities," J. Lightwave Technol. 24, 4876-4884 (2006).

34. S. Chandrasekhar and X. Liu, "Enabling components for future high-speed coherent communication systems," in Proc. OFC/NFOEC 2011 (Los Angeles, CA, USA, March 2011), CD, paper OMU5.

35. OIF, "100 G ultra long Haul DWDM framework document," www.oiforum.com.

36. H. Yamazaki, T. Yamada, K. Suzuki, T Goh, A Kaneko, A. Sano, E. Yamada, and Y. Miyamoto, "Integrated 100-Gb/s PDM-QPSK modulator using a hybrid assembly technique with silica-based PLCs and LiNbO3 phase modulators," in Proc. ECOC 2008 (Brussels, Belgium, 2008), CD, paper Mo.3.C.1.

37. K. Prosyk, A. Ait-Ouali, C. Bornholdt, T. Brast, M. Gruner, M. Hamacher, D. Hoffmann, R. Kaiser, R. Millett, K.-O. Velthaus, and I. Woods, "High performance $40 \mathrm{GHz} \mathrm{InP}$ Mach-Zehnder modulator," in Proc. OFC 2012 (Los Angeles, CA, USA, March 2012), CD, paper OW4F.7.

38. N. Kono, T. Kitamura, H. Yagi, N. Itabashi, T. Tatsumi, Y. Yamauchi, K. Fujii, K. Horino, S. Yamanaka, K. Tanaka, K. Yamaji, C. Fukuda, and H. Shoji, "Compact and low power DP-QPSK modulator module with InP-based modulator and driver ICs," in Proc. OFC 2013 (Anaheim, CA, USA, March 2013), CD, paper OW1G.2.

39. L. Stampoulidis, M. F. O’Keefe, E. Giacoumidis, R. G. Walker, Y. Zhou, N. Cameron, E. Kehayas, I. Tomkos, and L. Zimmermann, "Fabrication of the first high-speed GaAs IQ electro-optic modulator arrays and applicability study for low-cost Tb/s direct-detection optical OFDM networks," in Proc. OFC 2013 (Anaheim, CA, USA, March 2013), CD, paper OW1G.4.

40. B. Milivojevic, C. Raabe, A. Shastri, M. Webster, P. Metz, S. Sunder, B. Chattin, S. Wiese, B. Dama, and K. Shastri, "112 Gb/s DP-QPSK transmission over 2427 km SSMF using small-size silicon photonic IQ modulator and low-power CMOS driver," in Proc. OFC 2013 (Anaheim, CA, USA, March 2013), CD, paper OTh1D.1.

41. Y. Kurata, Y. Nasu, M. Tamura, R. Kasahara, S. Aozasa, T. Mizuno, H. Yokoyama, S. Tsunashima, and Y. Muramoto, "Silica-based PLC with heterogeneously-integrated PDs for one-chip DP-QPSK receiver,' Opt. Express 20, B264-B269 (2012).

42. K. Murata, T. Saida, K. Sano, I. Ogawa, H. Fukuyama, R. Kasahara, Y. Muramoto, H. Nosaka, S. Tsunashima, T. Mizuno, H. Tanobe, K. Hattori, T. Yoshimatsu, H. Kawakami, and E. Yoshida, "100-Gbit/s PDM-QPSK coherent receiver with wide dynamic range and excellent common-mode rejection ratio," Opt. Express 19, B125-B130 (2011).

43. J. Wang, C. Zawadzki, N. Mettbach, W. Brinker, Z. Zhang, D. Schmidt, N. Keil, N. Grote, and M. Schell, "Polarization insensitive 25-Gbaud direct $\mathrm{D}(\mathrm{Q}) \mathrm{PSK}$ receiver based on polymer planar lightwave hybrid integration platform," Opt. Express 19, 12197-12207 (2011).

44. P. Runge, S. Schubert, A. Seeger, K. Janiak, J. Stephan, D. Trommer, P. Domburg, and M. L. Nielsen, "Monolithic InP receiver chip with a $90^{\circ}$ hybrid and $56 \mathrm{GHz}$ balanced photodiodes," Opt. Express 20, B250-B255 (2012).

45. H. Yamazaki, T. Goh, T. Saida, Y. Hashizume, S. Mino, M. Nagatani, H. Nosaka, and K. Murata, "Dual-carrier dual-polarization IQ modulator driven with high-speed DACs for 400-Gb/s applications," in Proc. ECOC 2008 (Brussels, Belgium, 2008), CD, paper We.3.E.1.

46. M. Jinno, B. Kozicki, H. Takara, A. Watanabe, Y. Sone, T. Tanaka, and A. Hirano, "Distance-adaptive spectrum resource allocation in spectrum-sliced elastic optical path network," IEEE Commun. Mag. 48, 138-145 (2010).

47. R. Ryf, S. Randel, A. H. Gnauck, C. Bolle, A. Sierra, S. Mumtaz, M. Esmaeelpour, E. C. Burrows, R. Essiambre, P. J. Winzer, D. W. Peckham, A. H. McCurdy, and R. Lingle, "Mode-division multiplexing over $96 \mathrm{~km}$ of few-mode fiber using coherent $6 \times 6$ MIMO processing," J. Lightwave Technol. 30, 521-531 (2012).

48. S. Chandrasekhar, A. H. Gnauck, X. Liu, P. J. Winzer, Y. Pan, E. C. Burrows, T. F. Taunay, B. Zhu, M. Fishteyn, M. F. Yan, J. M. Fini, E. M. Monberg, and F. V. Dimarcello, "WDM/SDM transmission of $10 \times 128-\mathrm{Gb} / \mathrm{s}$ PDM-QPSK over 2688-km 7-core fiber with a per-fiber net aggregate spectral-efficiency distance product of $40,320 \mathrm{~km} \cdot \mathrm{b} / \mathrm{s} / \mathrm{Hz}$," Opt. Express 20, 706-711 (2012). 